\title{
Configuration-Dependent Medium-Sized Ring Formation: Chiral Molecular Framework with Three- Dimensional Architecture
}

\author{
Nadezda Cankarova, Agustina La Venia, Sona Krajcovicova, and Viktor Krchnak
}

J. Org. Chem., Just Accepted Manuscript • DOI: 10.1021/acs.joc.8b02465 • Publication Date (Web): 13 Dec 2018

Downloaded from http://pubs.acs.org on December 14, 2018

\section{Just Accepted}

"Just Accepted" manuscripts have been peer-reviewed and accepted for publication. They are posted online prior to technical editing, formatting for publication and author proofing. The American Chemical Society provides "Just Accepted" as a service to the research community to expedite the dissemination of scientific material as soon as possible after acceptance. "Just Accepted" manuscripts appear in full in PDF format accompanied by an HTML abstract. "Just Accepted" manuscripts have been fully peer reviewed, but should not be considered the official version of record. They are citable by the Digital Object Identifier (DOIB). "Just Accepted" is an optional service offered to authors. Therefore, the "Just Accepted" Web site may not include all articles that will be published in the journal. After a manuscript is technically edited and formatted, it will be removed from the "Just Accepted" Web site and published as an ASAP article. Note that technical editing may introduce minor changes to the manuscript text and/or graphics which could affect content, and all legal disclaimers and ethical guidelines that apply to the journal pertain. ACS cannot be held responsible for errors or consequences arising from the use of information contained in these "Just Accepted" manuscripts. 


\section{Configuration-Dependent Medium-Sized Ring Formation: Chiral Molecular Framework with Three-}

\section{Dimensional Architecture}

Naděžda Cankařová, ${ }^{a}$ Agustina La Venia, ${ }^{b \#}$ Soňa Krajčovičová, ${ }^{b}$ and Viktor Krchňák ${ }^{b, c *}$

Institute of Molecular and Translation Medicine, Faculty of Medicine, Palacký University, Hněvotínská 5, Olomouc, 779 00, Czech Republic

${ }^{b}$ Department of Organic Chemistry, Faculty of Science, Palacký University, 17. listopadu 12, 77146

Olomouc, Czech Republic

${ }^{c}$ Department of Chemistry and Biochemistry, 251 Nieuwland Science Center, University of Notre Dame, Notre Dame, Indiana 46556, United States

*Corresponding author. Email: vkrchnak@nd.edu.

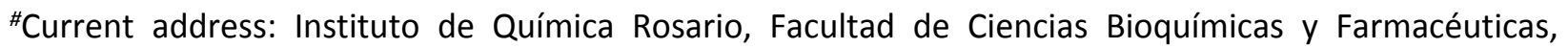
Universidad Nacional de Rosario-CONICET, Suipacha 531, S2002LRK, Rosario, Argentina

TOC

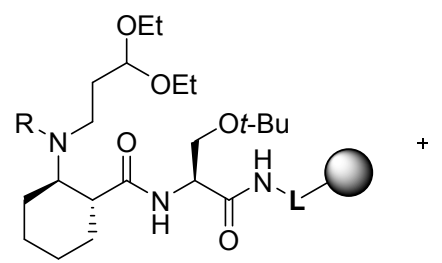

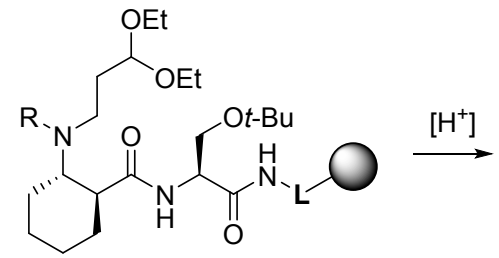

R: arylsulfonyl

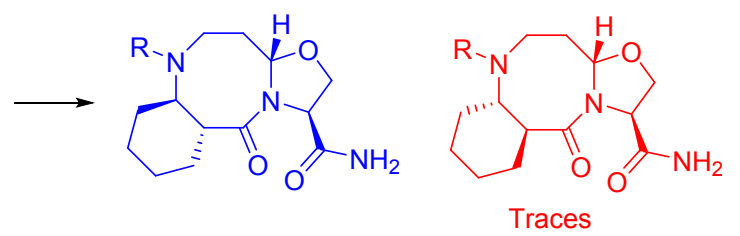

Keywords: 3D architecture, configuration, heterocycles, medium-sized rings, molecular scaffold, solidphase synthesis 


\section{Abstract}

This communication describes a configuration-dependent $[6+8+5]$ fused ring formation via a tandem cyclic $N$-acyliminium-nucleophilic addition reaction. Cyclization of the acyclic precursor prepared on the solid phase using L-Ser and racemic mixture of Fmoc-trans-2-aminocyclohexane carboxylic acid predominantly yielded the cyclic diastereomer with the $(1 R, 2 R)$-2-aminocyclohexane moiety rather than the tricyclic diastereomer from the $(1 S, 2 S)$-enantiomer. In contrast, the model compound prepared with D-Ser predominantly cyclized with the $(1 S, 2 S)$-2-aminocyclohexane carboxylic acid substrate. The outcome of the cyclization was not influenced by the type of resin, the spacer or the $\mathrm{N}$-substituent. The analogous synthesis of the $[6+7+5]$ fused ring system yielded an inseparable diastereomers in a 1:0.6 ratio.

\section{Introduction}

Today, the search for new drugs is focused on the design and synthesis of compounds structurally resembling natural products, which is referred to as biology-oriented synthesis. ${ }^{1-5}$ The structural analysis of compound collections used for hit/lead generation revealed that chiral molecular scaffolds with three-dimensional (3D) architecture that mimic natural products show greater potential for finding promising starting compounds for the discovery of novel lead compounds. ${ }^{6,7}$ Several synthetic strategies have been devised for accessing chiral 3D molecular frameworks. Tandem iminium ion cyclizations followed by nucleophilic additions have been one of the most attractive methods since it generates two rings in one step and induces the formation of a new stereogenic center, typically with full control of the stereochemistry. ${ }^{8-11}$ Several groups, including ours, have been involved in the synthesis of chiral molecular scaffolds comprising fused/bridged rings using iminium chemistry (for reviews, see ${ }^{10,12,13}$ ).

Our work has focused on the stepwise solid-phase synthesis of acyclic intermediates I (Scheme 1) using simple and commercially available building blocks, Fmoc-amino acids, nitrobenzenesulfonyl chlorides 
(Nos-Cl) and protected hydroxyaldehydes. Acid-mediated cleavage from resin I provided access to fused bis-heterocycles III; the first ring was formed by cyclization to $\mathrm{N}$-acyliminium II, and the second ring closure occurred via nucleophilic addition. ${ }^{14,15}$

Scheme 1. General route to fused molecular frameworks with different ring sizes

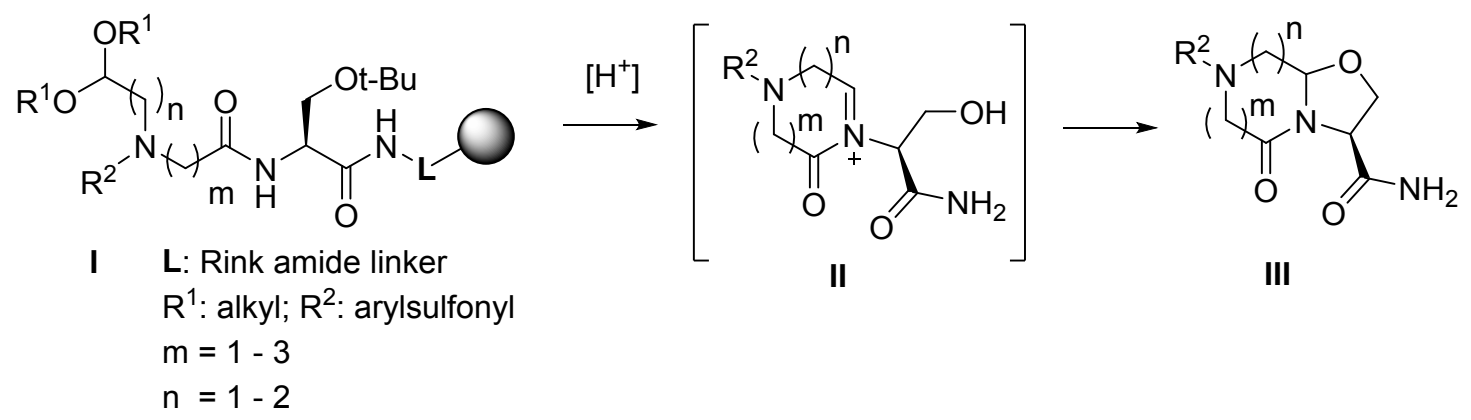

The size of the first ring (cyclic iminium ion II) can be expanded from six- to seven- and even eightmembered rings by using either $\alpha$-, $\beta$ - or $\gamma$-amino acids $(m=1,2$, and 3$)$ combined with aldehydes with two- or three-carbon spacers ( $n=1$ and 2 ). In a recent report, we showed that compounds with sevenand eight-membered rings were not formed when $\beta$ - and $\nu$-amino acids were used in combination with two-carbon spacer (structures in red, Figure 1). ${ }^{14}$ However, $\mathrm{N}$ - $\alpha$-amino acids in combination with aldehydes containing three-carbon spacers readily generated larger rings (structures in black, Figure 1). The ring formation depends on the population of the conformer capable of closing the iminium ring. Reducing the conformational space, enhancing the population of conformers prone to cyclization, has a positive effect on the cyclization outcome (for review see ${ }^{16,17}$ ). Indeed, we recently applied this strategy to the synthesis of 11-membered fused rings. ${ }^{18}$ In this communication, we describe the insertion of a conformational constraint by incorporating a 2-aminocyclohexane carboxylic acid instead of a $\beta$-Ala and successful cyclization to a seven-membered ring and, more interestingly, configuration-dependent eightmembered ring formation (structures in blue, Figure 1). 
Figure 1. Color-coded medium-sized fused heterocycles (red: not formed; black: formed; blue: reported in this communication)
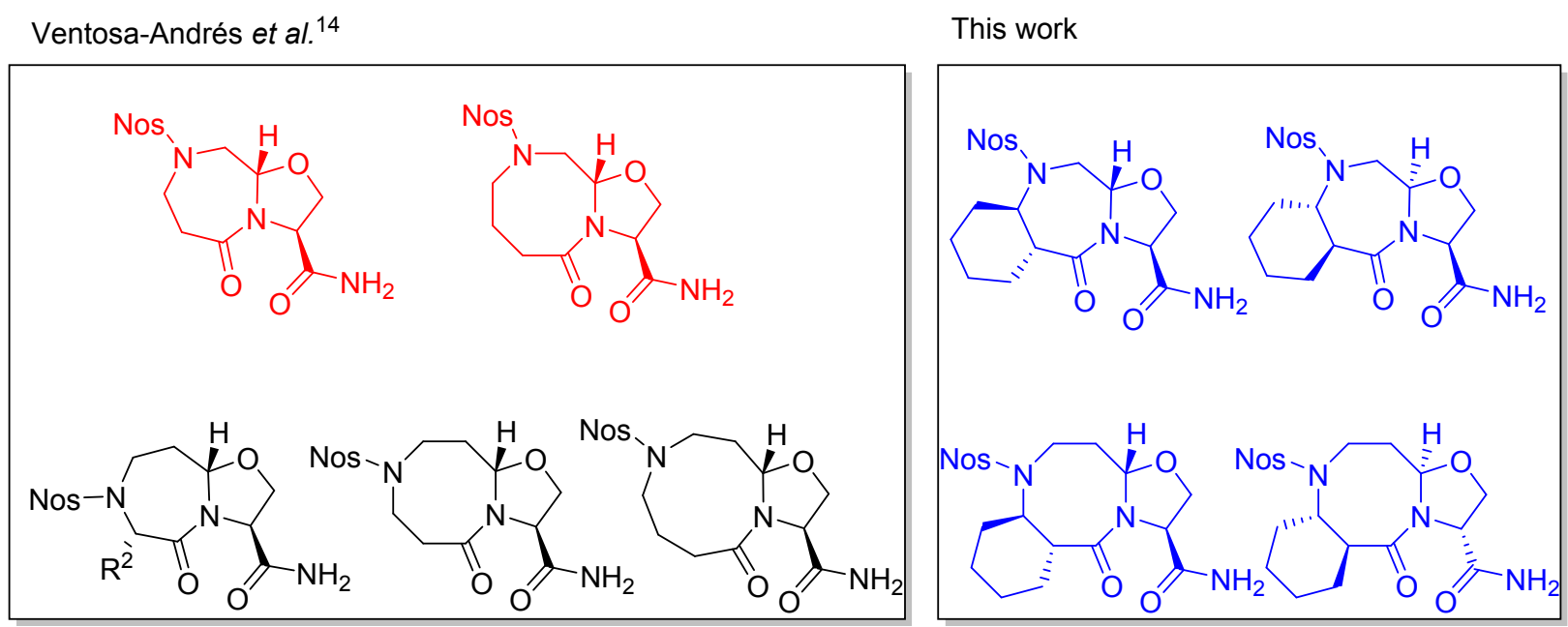

\section{Results and Discussion}

To address the effect of constrained chiral building blocks and their configurations on the favorability of forming seven- and eight-membered rings, we prepared model compounds using both enantiomers of Fmoc-trans-2-aminocyclohexane carboxylic acid, Fmoc-L- and D-Ser(tBu)-OH, 4-Nos-Cl, and 2,2dimethoxyethan-1-ol (for the seven-membered ring) or 3,3-diethoxypropan-1-ol (for the eightmembered ring).

\section{Synthesis}

Briefly, polystyrene (PS) Rink amide resin 1a was treated with $50 \%$ piperidine in DMF, and the primary amino group was acylated with Fmoc-L-Ser(tBu)-OH (or Fmoc-D-Ser(tBu)-OH, discussed later) via activation with diisopropylcarbodiimide (DIC) and 1-hydroxybenzotriazole (HOBt) (Scheme 2). The Fmocprotecting group was subsequently cleaved, and the primary amine was acylated with a racemic mixture of Fmoc-trans-2-aminocyclohexane carboxylic acids to afford resin 2. The Fmoc group was cleaved, and the amino group was reacted with 4-Nos-Cl in the presence of 2,6-lutidine (resin 3). Notably, both 
enantiomers of trans-2-aminocyclohexane carboxylic acid reacted with the resin-bound Ser based on ${ }^{1} \mathrm{H}$ NMR analysis of the analytical sample of intermediate $\mathbf{3}$ after release from the resin. Polymer-supported sulfonamide 3 was then subjected to the Fukuyama modification ${ }^{19}$ of Mitsunobu alkylation ${ }^{20}$ with 3,3diethoxypropan-1-ol (or 2,2-dimethoxyethan-1-ol) to form corresponding substituted sulfonamides 4 (and $\mathbf{5}$ - built on TentaGel resin; discussed later). In agreement with our previous work, ${ }^{21,22}$ Mitsunobu alkylation was not quantitative despite numerous attempts to optimize the reaction conditions. The best results were obtained by doubling the volume of reagent solution $(2 \mathrm{~mL}$ of solution per $100 \mathrm{mg}$ of resin; i.e., 8 equivalents) and repeated reaction. According to the LC traces, $30 \%$ of the starting material remained after the overnight Mitsunobu reaction and only $4 \%$ remained after repeating the alkylation.

The model experiments were carried out with Nos-derivatives so our results could be compared with previously synthesized analogous compounds. ${ }^{14}$ However, the Nos-activating/protecting group can be cleanly cleaved with 2-mercaptoethanol in the presence of DBU for further elaboration of the secondary amino group.

Scheme 2. Synthesis of resin-bound constrained precursors $\mathbf{4}$ and $\mathbf{5}^{\mathbf{a}}$

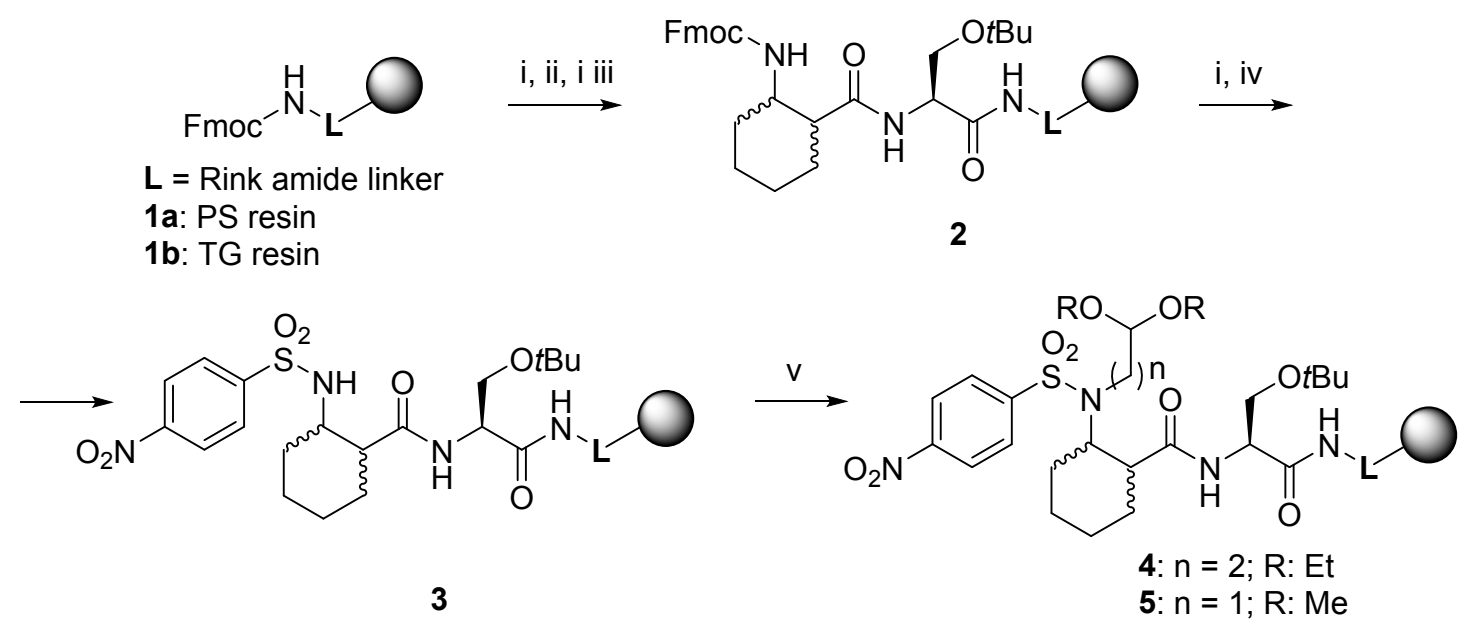

aReagents and conditions: (i) 50\% piperidine in DMF, rt, $15 \mathrm{~min}$; (ii) Fmoc-L-Ser(tBu)-OH (or Fmoc-D$\operatorname{Ser}(t B u)-O H$ - not drawn), HOBt, DIC, DCM/DMF (1:1), rt, 16 h; (iii) Fmoc-trans-2-aminocyclohexane 
carboxylic acid (for other isomers, see Experimental Procedure), HOBt, DIC, DCM/DMF (1:1), rt, 16 h; (iv) 4-Nos-Cl, 2,6-lutidine, DCM, rt, 4 h; (v) 3,3-diethoxypropan-1-ol $(n=2)$ (or 2,2-dimethoxyethan-1-ol, $n=$ 1), $\mathrm{PPh}_{3}, \mathrm{DIAD}$, anhydrous $\mathrm{THF}, 0^{\circ} \mathrm{C}, 30 \mathrm{~min}$, then $\mathrm{rt}, 16 \mathrm{~h}$, repeated.

\section{Cyclization to $[6+8+5]$ fused rings}

Standard acidic cleavage of acyclic precursors 4 from the polymer support ( $50 \%$ TFA in DCM, rt, $30 \mathrm{~min}$ ) used in routine analyses afforded a major peak for cyclic hemiaminal $7^{23}$ in addition to a peak for cyclized product 6 (Scheme 3). To improve the cyclization to target products 6 , the reaction time was extended to overnight (product $(\boldsymbol{S}, \boldsymbol{S}, \boldsymbol{R}, \boldsymbol{R})-\mathbf{6}$, Entry 1, Table S1, Supporting Information, SI). The extension of the reaction time led to better reaction outcomes (peak of the product significantly increased) despite the growth of a peak for compound $\mathbf{8}$, formed by competitive release of acrolein from intermediate 7. Analogous cleavage from structurally related substrates has been reported previously. ${ }^{23}$ To prevent the undesirable competitive loss of the enal, we tested cleavage conditions involving neat $\mathrm{HCOOH}$ at $50^{\circ} \mathrm{C}$ overnight (product $(S, S, R, R)-6$, Entry 2, Table S1). LC/MS analysis revealed the presence of a major peak (39\%) corresponding to product 6; nevertheless, a significant peak (31\%) from formylated intermediate 9 was also observed (Scheme 3). In summary, products obtained from different cleavage/cyclization conditions (50\% TFA in DCM, rt, on - Entry $1 ; \mathrm{HCOOH}, 50^{\circ} \mathrm{C}$, on - Entry 2) showed similar isolated yields (12\% and 10\%). Moreover, both products were analyzed by ${ }^{1} \mathrm{H}$ and ${ }^{13} \mathrm{C}$ NMR spectroscopy, which confirmed that their structures were identical.

Scheme 3. Composition of crude products obtained using different cleavage cocktails ${ }^{a}$ 
<smiles>[13CH3]</smiles><smiles>NC(=O)[C@@H]1CO[C@H]2CCN([S@](=O)c3ccc([N+](=O)[O-])cc3)[C@@H]3CCCC[C@H]3C(=O)N21</smiles>

(S,S,R,R)-6<smiles>NC(=O)[C@@H]1CO[C@H]2CCN(S(=O)c3ccc([N+](=O)[O-])cc3)[C@@H]3CCCC[C@H]3C(=O)N21</smiles>

$(S, S, S, S)-6$ trace<smiles>NC(=O)C(CO)N1C(=O)[C@@H]2CCCC[C@H]2N([S@](=O)c2ccc([N+](=O)[O-])cc2)CCC1O</smiles>

7<smiles>NC(=O)[C@H](CO)NC(=O)[C@@H]1CCCC[C@H]1N[SH](=O)([O-])c1ccc([N+](=O)[O-])cc1</smiles>

8<smiles>NC(=O)[C@H](COC=O)N1C=CCN([S@](=O)(O)c2ccc([N+](=O)[O-])cc2)[C@@H]2CCCC[C@H]2C1=O</smiles>

9

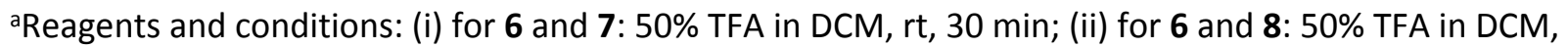
rt, $16 \mathrm{~h}$; (iii) for 6 and 9: neat $\mathrm{HCOOH}, 50^{\circ} \mathrm{C}, 16 \mathrm{~h}$.

\section{Structure determination}

Exhaustive ${ }^{1} \mathrm{H}$ and ${ }^{13} \mathrm{C}$ NMR analysis revealed very interesting results. Despite the use of a racemic mixture of Fmoc-trans-2-aminocyclohexane carboxylic acid, one diastereomer was preferentially formed (Entry 1, Table S1). To verify that the commercial Fmoc-trans-2-aminocyclohexane carboxylic acid is the anticipated racemic mixture, we analyzed the original acid by chiral supercritical fluid chromatography (SFC) and proved the equimolar ratio of both enantiomers (for more information, see the $\mathrm{SI}$ ).

A set of 1D- and 2D-NMR experiments, including ${ }^{1} \mathrm{H},{ }^{13} \mathrm{C},{ }^{1} \mathrm{H}-{ }^{13} \mathrm{C} \mathrm{HSQC},{ }^{1} \mathrm{H}-{ }^{13} \mathrm{C} \mathrm{HMBC}, 2 \mathrm{D}$ NOESY, and 1D NOE, were carried out to determine the absolute configuration of the chiral carbons. The absolute stereochemistry of the newly formed stereogenic center was determined from the strong NOE correlations between the $3 a-H, 4-H_{b}$ and $10 a-H$ protons in 2D NOESY spectrum and the $3 a-H$ and $10 a-H$ protons in the 1D NOE spectrum (in blue, Figure 2). The 1-C chiral carbon was introduced by commercially available and optically pure L-Ser; therefore, its configuration was known. Further NOE correlations of the $1-\mathrm{H}$ proton with $2-\mathrm{H}_{b}$ and $2-\mathrm{H}_{b}$ with $4-\mathrm{H}_{a}$, as well as correlations of $6 \mathrm{a}-\mathrm{H}$ with $4-\mathrm{H}_{a}$ (in red) and $5-\mathrm{H}_{\mathrm{b}}$ with $4-\mathrm{H}_{\mathrm{b}}$ (in blue), confirmed the proposed stereochemistry of the final product. 
Figure 2. Configuration assignment of $(S, S, R, R)-6$ based on NOE experiments (in blue: above the plane; in red: under the plane)

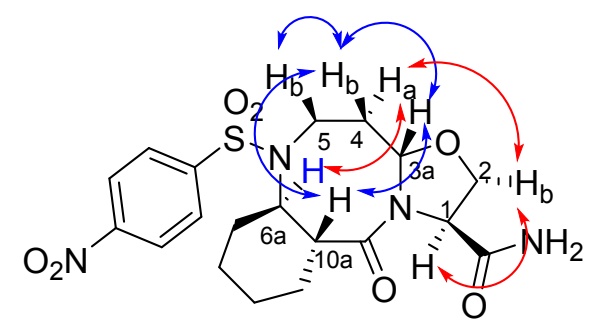

$(S, S, R, R)-6$

To independently confirm the absolute configuration of chiral carbons $3 a, 6 a$ and $10 a$, we synthesized resin-bound intermediates 4 with optically pure amino acids, Fmoc-(1R,2R)-2-aminocyclohexane carboxylic acid (resin $(\boldsymbol{S}, \boldsymbol{R}, \boldsymbol{R})-\mathbf{2})$ and Fmoc-(1S,2S)-2-aminocyclohexane carboxylic acid (resin $(\boldsymbol{S}, \boldsymbol{S}, \boldsymbol{S})-\mathbf{2})$, according to Scheme 2. We observed differences in the reactivities of these two diastereomers. The intermediate containing $(1 R, 2 R)$-2-aminocyclohexane carboxylic acid $(\boldsymbol{S}, \boldsymbol{R}, \boldsymbol{R})$-2 smoothly underwent Mitsunobu alkylation (resin 4 ) and provided target product $(\boldsymbol{S}, \boldsymbol{S}, \boldsymbol{R}, \boldsymbol{R})-\mathbf{6}$ (Entry 3 , Table S1) in high purity (75\%); however, the cyclization of intermediate comprising (1S,2S)-2-aminocyclohexane carboxylic acid $(\boldsymbol{S}, S, S)-4$ to product $(\boldsymbol{S}, S, S, S)-6$ (Entry 4$)$ was very sluggish (Scheme 4$)$. The yield of purified product $(\boldsymbol{S}, \boldsymbol{S}, \boldsymbol{R}, \boldsymbol{R})-\mathbf{6}$ was $24 \%$, whereas the yield of $(\boldsymbol{S}, \boldsymbol{S}, \boldsymbol{S}, \boldsymbol{S})-\mathbf{6}$ was only $3 \%$. In addition to confirming the configuration of the chiral carbons, the NMR spectra of $(\boldsymbol{S}, S, \boldsymbol{R}, \boldsymbol{R})-\mathbf{6}$ (Entry 3 , Table S1) were identical to the spectra of the product obtained by using racemic mixture of the cyclic amino acids (Entry 1$)$.

Scheme 4. The effect of configuration of the 2-aminocyclohexane carboxylic acid on the final cyclization product $^{a}$ 


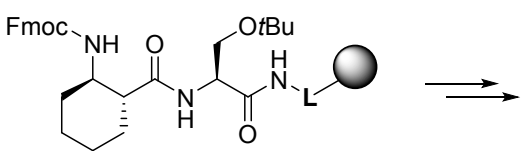

$(S, R, R)-2$

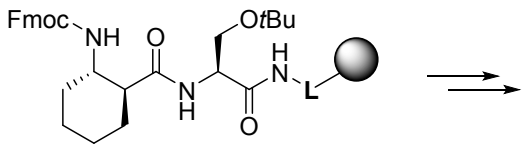

$(S, S, S)-2$<smiles>CCOCC(OCC)C(=O)NC(=O)C1CCCCC1N(CCC(OCC)OCC)S(=O)c1ccc([N+](=O)[O-])cc1</smiles>

$(S, R, R)-4$

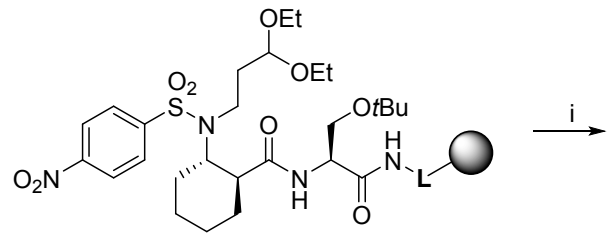

$(S, S, S)-4$<smiles>NC(=O)[C@@H]1CO[C@H]2CCN([O-])[C@@H]3CCCC[C@H]3C(=O)N21</smiles>

$(S, S, R, R)-6$ $24 \%$ yield<smiles>NC(=O)[C@@H]1CO[C@H]2CCN([O-])[C@H]3CCCC[C@H]3C(=O)N21</smiles>

$(S, S, S, S)-6$ $3 \%$ yield

aReagents and conditions: (i) 50\% TFA in DCM, rt, $16 \mathrm{~h}$.

To consider all possible configurations of the constrained amino acid and evaluate their impact on the configuration on the new stereogenic center, we prepared compounds from L-Ser and a racemic mixture of Fmoc-cis-2-aminocyclohexane carboxylic acids and obtained cyclic product $(\boldsymbol{S}, \boldsymbol{S}, \boldsymbol{S}, \boldsymbol{R})$ - 6 (Entry 5 , Table S1). The configurations of the chiral carbons in the constrained amino acids as well as that of the newly formed chiral center at 3a-C were further investigated by 1D- and 2D-NMR experiments (Figure 3). The configuration of chiral $3 \mathrm{a}-\mathrm{C}$ was controlled by the presence of chiral carbon $1-\mathrm{C}$ originating from optically pure L-Ser, analogously to what was seen with the trans-2-aminocyclohexane moietycontaining compound. The absolute configuration of $6 \mathrm{a}-\mathrm{H}$ and $10 \mathrm{a}-\mathrm{H}$ was determined from the NOE correlations between $3 \mathrm{a}-\mathrm{H}, 6 \mathrm{a}-\mathrm{H}$ and $10 \mathrm{a}-\mathrm{H}$. The results of this experiment are consistent with those of the experiments utilizing trans-aminocyclohexane carboxylic acid and confirmed the dependence of the configuration of $3 \mathrm{a}-\mathrm{C}$ on the Ser, not on the constrained amino acid.

Figure 3. Configuration assignment of $(S, S, S, R)-6$ based on NOE experiments (in blue) 


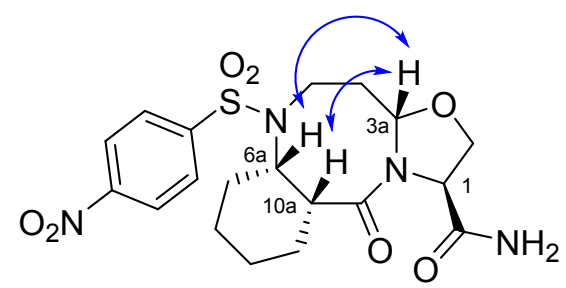

$(S, S, S, R)-6$

Next, we evaluated the effect of the configuration of Ser on the outcome of the cyclization and prepared three acyclic precursors (analogously to precursor 4 in Scheme 2) using D-Ser as a starting building block and trans-, $(1 R, 2 R)$ - and $(1 S, 2 S)$-2-aminocyclohexane carboxylic acids in the next step of the synthesis. As expected, in contrast to the results with the L-Ser-containing compound, the cyclizations with the D-Sercontaining substrates were more successful with the $(1 S, 2 S)$-2-aminocyclohexane carboxylic acid model compound and presented the same stereoselectivity, and the reactions generated tricycle $(\boldsymbol{R}, \boldsymbol{R}, \boldsymbol{S}, \boldsymbol{S})-\mathbf{6}$ in 63\% yield (Figure 4 and Entry 7, Table S1). We also prepared the D-Ser-compound with a racemic mixture of trans-2-aminocyclohexane carboxylic acids. Analysis of the cyclization revealed the predominant formation of the $S, S$-isomer $(\boldsymbol{R}, \boldsymbol{R}, \boldsymbol{S}, \boldsymbol{S})-\mathbf{6}$ (Entry 6).

In all the model systems, the presence of D-Ser caused newly formed chiral carbon 3a to take on an $R$ configuration. The structures of enantiomers of the products generated from favorable combinations of building blocks are shown in Figure 4 . In conclusion, the Ser-configuration was the decisive factor in selecting which enantiomer of 2-aminocyclohexane carboxylic acid would participate in the cyclization, and in general, the D-configuration of Ser enhanced the yields of the final products (compare entries 1, 3 and 4 versus entries $6-8$, Table S1).

Figure 4. The effect of the configuration on Ser on the final cyclization 


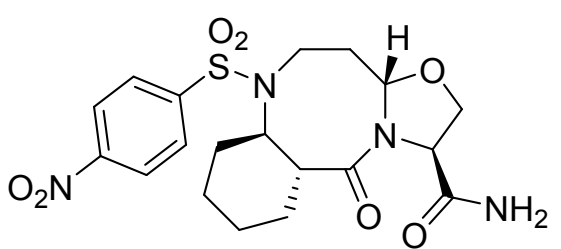

$(S, S, R, R)-6$

$24 \%$ yield<smiles>NC(=O)[C@@H]1CO[C@@H]2CCN([O-])[C@H]3CCCC[C@H]3C(=O)N12</smiles>

$(R, R, S, S)-6$

$63 \%$ yield

To summarize, we observed an unprecedented dependence of a cyclization on the chirality of the acyclic precursors. This configuration-driven cyclization prompted us to explore the structural factors influencing this selectivity. We carried out several model syntheses designed to reveal the effect of (i) the type of resin, (ii) the distance between the core structure and the resin, (iii) the $\mathrm{N}$-substituent, and (iv) reducing the size of the iminium ring to a seven-membered ring. The effect of the resin type and spacer has been reported on structurally unrelated reactions. ${ }^{24}$

\section{Type of resin}

To evaluate the potential effects of the hydrophobicity of the polymer support, we exchanged PS Rink resin for hydrophilic TentaGel (TG) Rink resin 1b (Scheme 2). However, the use of different types of solid support did not change the outcome of the cyclization reaction. Only a slight difference in the yield was observed; product $(\boldsymbol{S}, \boldsymbol{S}, \boldsymbol{R}, \boldsymbol{R})-\mathbf{6}$ built on PS resin (Entry 1, Table S1) was obtained in $12 \%$ yield, while product from TG resin (Entry 9) was obtained in $8 \%$ yield.

\section{Inserting a spacer between the resin and the substrate}

Furthermore, to exclude the effect of the proximity of the reaction centers to the bulky Rink amide resin, we also synthesized analogous compound on PS Rink resin 1a that had been acylated with 4aminomethylbenzoic (AMB) acid (Scheme 5).

Scheme 5. Incorporation of AMB spacer between the Rink amide resin and the substrate ${ }^{a}$ 


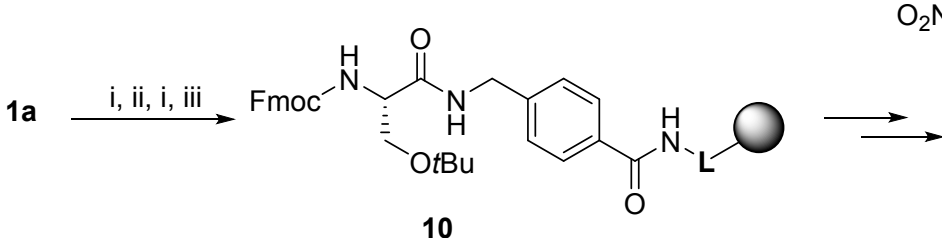<smiles>O=[N+]([O-])c1ccc(S(=O)(=O)[O-])cc1</smiles><smiles>CCOC(CCN(O)S(=O)(=O)c1ccccc1)OCC</smiles>

10

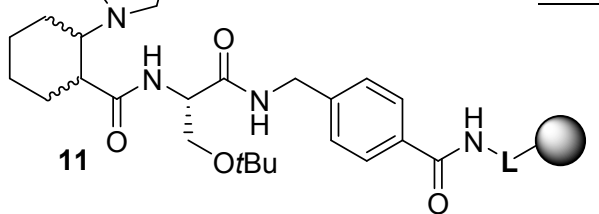

aReagents and conditions: (i) 50\% piperidine in DMF, rt, 15 min; (ii) 4-(Fmoc-aminomethyl)benzoic acid (1 equiv.), HOBt (1 equiv.), DIC (1 equiv.), DCM/DMF (1:1), rt, 16 h; (iii) Fmoc-L-Ser(tBu)-OH (1 equiv.), HOBt (1 equiv.), DIC (1 equiv.), DCM/DMF (1:1), rt, 16 h; (iv) 50\% TFA in DCM, rt, 16 h.

Cleavage from intermediate $\mathbf{1 1}$ and concurrent cyclization resulted in products analogous to that generated without the AMB linker; the major diastereomer contained the $(1 R, 2 R)$-2-aminocyclohexane carboxylic acid moiety $(S, S, R, R)-\mathbf{1 2}$. Both diastereomers of $\mathbf{1 2}$ were isolated, and their ${ }^{1} \mathrm{H}$ NMR spectra revealed the presence of diagnostic proton signals with chemical shifts of $\delta=5.82 \mathrm{ppm}$ for the major diastereomer and $\delta=5.68 \mathrm{ppm}$ for the minor stereoisomer, confirming the closure of the second ring. These data were consistent with the analysis of the major $(\delta=5.75 \mathrm{ppm})$ and minor $(\delta=5.62 \mathrm{ppm})$ isomers of 6 generated without the AMB spacer.

\section{N-Substituent}

To investigate the influence of the substitution of the $N$-arylsulfonyl moiety, the originally used 4-Nos group was replaced by other arylsulfonyl groups using 2-nitro-4-(trifluoromethyl)benzenesulfonyl chloride (products 13 and 16 (compound containing the AMB spacer), Table S1), 2,4dinitrobenzenesulfonyl chloride (14 and 17), and 2-nitrobenzenesulfonyl chloride (15 and 18). The results indicated that the substituents had no influence on the outcome of the configuration-dependent 
cyclization of either type of product (with or without the AMB spacer); although the purities and yields varied, all experiments afforded analogous products (for detailed information, see the SI).

\section{Cyclization to $[6+7+5]$ fused rings}

Finally, to evaluate the effect of iminium ring size, we prepared analogous scaffold containing $[6+7+5]$ fused rings. The synthesis of resin-bound precursor 5 was carried out using a racemic mixture of Fmoctrans-2-aminocyclohexane carboxylic acids, and the reaction conditions are shown in Scheme 2. Interestingly, in contrast to the previously reported results ${ }^{14}$ in which the synthesis of the 7-membered ring failed when a 2-carbon masked aldehyde was used, target product 19 was successfully synthesized. This result proved that constrained conformations of the acyclic precursor caused by the presence of a cyclic amino acid were essential to the success of the ring closure. The synthesis proceeded analogously to the synthesis described above. However, the standard cleavage/cyclization conditions (50\% TFA in $\mathrm{DCM}, \mathrm{rt}, 16 \mathrm{~h}$ ) did not lead to quantitative cyclization to the target product (approximately $39 \%$ of noncyclized aldehyde remained, and only $18 \%$ of the cyclized product was obtained). Therefore, we used neat $\mathrm{HCOOH}$ for the final step of the synthesis, and the reaction proceeded at elevated temperature $\left(50^{\circ} \mathrm{C}\right)$ overnight; the crude purity was $37 \%$.

The product was purified using RP HPLC with MeCN/aqueous $10 \mathrm{mM}$ ammonium acetate as the mobile phases, and the product eluted as a single peak. However, the ${ }^{1} \mathrm{H}$ NMR spectrum revealed the presence of both diastereomers, $(S, R, R, S)-19$ and $(S, S, S, R)-19$, and they were present in a ratio 1:0.6. We confirmed the structures of both diastereomers in the mixture by NMR experiments $\left({ }^{1} \mathrm{H},{ }^{13} \mathrm{C}, \mathrm{COSY},{ }^{1} \mathrm{H}\right.$ ${ }^{13} \mathrm{C} \mathrm{HSQC},{ }^{1} \mathrm{H}-{ }^{13} \mathrm{C} \mathrm{HMBC}$, and $2 \mathrm{D}$ NOESY; Figure 5). The chiral center at 3-C was introduced by commercially available and optically pure L-Ser, and its configuration was therefore known. The absolute configuration of the new stereogenic center at $11 \mathrm{a}-\mathrm{C}$ was determined to be $(S)$ for the major isomer $((S, R, R, S)-19)$ and $(R)$ for the minor isomer $((S, S, S, R)-19)$, analogously to previous stereoselectivity 
guided by Ser, from the strong ${ }^{1} \mathrm{H}$ NOESY correlations: the major diastereomer showed correlations between $11 \mathrm{a}-\mathrm{H}$ and $2-\mathrm{H}_{\mathrm{a}}$ and between $11 \mathrm{a}-\mathrm{H}, 11-\mathrm{H}_{\mathrm{a}}$ and $5 \mathrm{a}-\mathrm{H}$, which confirmed the stereochemistry of $(S, R, R, S)-19$ (Figure 5). The correlations between $2-H_{b}, 11 a-H$ and $3-H$, as well as the correlations between $11 \mathrm{a}-\mathrm{H}, 5 \mathrm{a}-\mathrm{H}$ and $11-\mathrm{H}_{b}$, confirmed the stereochemistry of minor isomer $(\boldsymbol{S}, S, S, R)-19$.

Figure 5. Configuration assignment of products $(S, R, R, S)-19$ and $(S, S, S, R)-19$ based on NOE experiments (in blue)

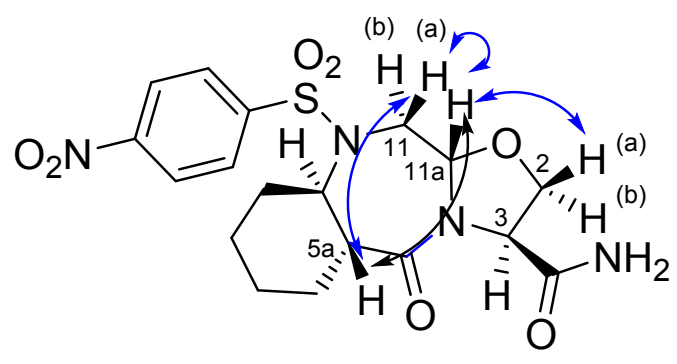

$(S, R, R, S)-19$ major

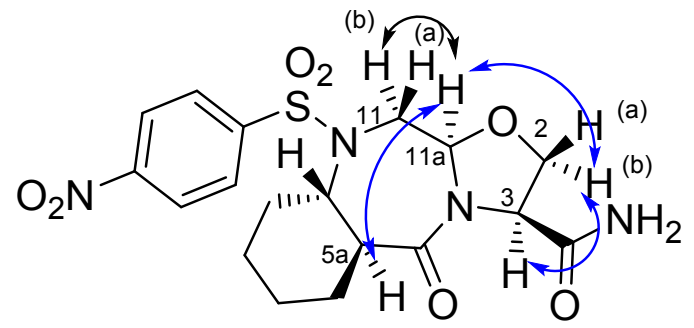

$(S, S, S, R)-19$ minor

\section{Conclusion}

We prepared chiral fused heterocycles with 3D architectures using tandem cyclic $\mathrm{N}$-acyliminium nucleophilic addition reactions. The introduction of constrained amino acids achieved challenging heterocyclizations, which were not feasible with the linear analogous substrates. The acyclic intermediate prepared on a solid support using L-Ser and racemic mixture of trans-2-aminocyclohexane carboxylic acid formed predominantly one diastereomer of the $[6+8+5]$ tricyclic fused ring. Cyclization of a precursor synthesized from L-Ser and $(1 R, 2 R)$-2-aminocyclohexane carboxylic acid afforded the expected $[6+8+5]$ tricyclic scaffold, whereas the $(1 S, 2 S)$-2-aminocyclohexane carboxylic acid-derived compound yielded only traces of the desired product. The configuration-driven selectivity was caused by the presence of a chiral center in Ser. The L-Ser-containing intermediate prepared using $(1 R, 2 R)-2$ - 
aminocyclohexane carboxylic acid afforded cyclic products, whereas the D-Ser-containing compound selected $(1 S, 2 S)$-2-aminocyclohexane carboxylic acid substrate for the cyclization. In addition, the stereoselectivity of the new chiral center generated during the second cyclization was mainly determined by the configuration of the serine amino acid. The synthesis proceeded under mild reaction conditions and utilized commercially available building blocks. The structures were unambiguously determined by 1D- and 2D-NMR experiments.

\section{Experimental Section}

General Information. All used chemical reagents were purchased from commercial sources. Solvents were reagent grade and used without further purification. Rink amide polystyrene resin (100-200 mesh, 1\% DVB, $0.61 \mathrm{mmol} / \mathrm{g})$ and Rink TentaGel HL RAM resin $(0.37 \mathrm{mmol} / \mathrm{g})$ were used and the solid-phase syntheses were performed in plastic reaction vessels (syringes, each equipped with a porous disc) using a manually operated synthesizer (www.torviq.com). ${ }^{25}$ The yields of the crude products were calculated with respect to the loading of the first building block.

The volume of wash solvent was $10 \mathrm{~mL}$ per $1 \mathrm{~g}$ of resin (except Mitsunobu alkylation; the volume was 20 $\mathrm{mL}$ per $1 \mathrm{~g}$ of resin). For washing, resin slurry was shaken with the fresh solvent for at least 1 minute before changing the solvent. After adding a reagent solution, the resin slurry was manually vigorously shaken to break any potential resin clumps. Resin-bound intermediates were dried by a stream of nitrogen for prolonged storage and/or quantitative analysis.

For the LC/MS analysis a sample of resin $(\sim 5 \mathrm{mg})$ was treated by 50\% TFA in DCM, the cleavage cocktail was evaporated by a stream of nitrogen, and cleaved compounds extracted into $1 \mathrm{~mL}$ of $\mathrm{MeOH}$. The LC/MS analyses were carried out using Acquity UPLC H class system (Waters, Massachusetts, USA) comprised $3 \times 50 \mathrm{~mm} \mathrm{C18}$ reverse phase column, $2.5 \mu \mathrm{m}$ particles at $25^{\circ} \mathrm{C}$ and with a flow rate of 600 $\mu \mathrm{l} / \mathrm{min}$. Mobile phases: $10 \mathrm{mM}$ ammonium acetate in HPLC grade water (A) and HPLC grade acetonitrile 
(B). The MS electrospray source operated at capillary voltage $0.8 \mathrm{kV}$, probe temperature $600^{\circ} \mathrm{C}$, and source temperature $120^{\circ} \mathrm{C}$.

The supercritical fluid chromatography system UPC2 (Waters) was used with photodiode array detector and QDa mass detector. Data acquisition was performed using MassLynx. The separations were accomplished using stationary phase with $100 \times 4.6 \mathrm{~mm}$ and particle size 3 um CHIRALPAK $^{\circledR}$ IB-3 (DAICEL Corporation). Isocratic elution was performed using $\mathrm{CO}_{2}$ with $20 \% \mathrm{MeOH}$ modified with $1 \% \mathrm{H}_{2} \mathrm{O}$, and $0,1 \%$ TFA. Flow rate was set $2.2 \mathrm{~mL} / \mathrm{min}$, the temperature at $38^{\circ} \mathrm{C}, \mathrm{ABPR} 2000 \mathrm{psi}$, the temperature of autosampler was set at $10^{\circ} \mathrm{C}$. The injected volume was $2 \mathrm{ul}$.

Purification was carried out on C18 reverse phase column $19 \times 100 \mathrm{~mm}, 5 \mu \mathrm{m}$ particles, and 6 minutes gradient was formed from $10 \mathrm{mM}$ aqueous ammonium acetate and acetonitrile on different proportions with a flow rate of $15 \mathrm{~mL} / \mathrm{min}$.

All ${ }^{1} \mathrm{H}$ and ${ }^{13} \mathrm{C}$ NMR experiments were performed at magnetic field strengths of $11.75 \mathrm{~T}$ (with operating frequencies $500.16 \mathrm{MHz}$ for ${ }^{1} \mathrm{H}$ and $125.77 \mathrm{MHz}$ for ${ }^{13} \mathrm{C}$ ) and $9.39 \mathrm{~T}$ (with operating frequencies 399.78 $\mathrm{MHz}$ for ${ }^{1} \mathrm{H}$ and $100.53 \mathrm{MHz}$ for $\left.{ }^{13} \mathrm{C}\right)$ at ambient temperature $\left(\sim 21{ }^{\circ} \mathrm{C}\right)$. All ${ }^{1} \mathrm{H}$ and ${ }^{13} \mathrm{C}$ spectra were referenced relative to the signal of DMSO $\left({ }^{1} \mathrm{H} \delta=2.50 \mathrm{ppm},{ }^{13} \mathrm{C} \delta=39.51 \mathrm{ppm}\right)$.

\section{Experimental Procedure}

Cleavage of Fmoc-Protecting Group, Acylation with Fmoc-L-Ser(tBu)-OH/Fmoc-D-Ser(tBu)-OH, Cleavage of Fmoc-Protecting Group and Acylation with Fmoc-trans-2-aminocyclohexane/Fmoc-cis-2aminocyclohexane/Fmoc-(1R,2R)-2-aminocyclohexane/Fmoc-(1S,2S)-2-aminocyclohexane Carboxylic Acid (Resin 2). Rink resin (2 g) was swollen in DCM, washed three times with DMF, and treated with $50 \%$ piperidine in DMF for 15 minutes. The resin was washed three times with DMF and three times with DCM. A 0.3 M solution of appropriate stereoisomer of Fmoc-Ser(tBu)-OH (6 mmol, $2.3 \mathrm{~g})$, HOBt (6 mmol, $0.92 \mathrm{~g})$, and DIC (6 mmol, 0,982 mL) in $20 \mathrm{~mL}$ DCM/DMF (1:1) was added to the resin and the 
resin slurry was shaken at rt for 16 hours. The resin was washed three times with DMF and again treated with $50 \%$ piperidine in DMF for 15 minutes, washed three times with DMF and three times with DCM. A $0.3 \mathrm{M}$ solution of appropriate Fmoc-2-aminocyclohexane carboxylic acid (3 mmol, $1.096 \mathrm{~g}$ ), HOBt (3 mmol, $0.46 \mathrm{~g}$ ), and DIC (3 mmol, $0.464 \mathrm{~mL}$ ) in $10 \mathrm{~mL} \mathrm{DCM/DMF} \mathrm{(1:1)} \mathrm{was} \mathrm{added.} \mathrm{The} \mathrm{resin} \mathrm{slurry} \mathrm{shaken}$ at $\mathrm{rt}$ for 16 hours. The resin was washed three times with DMF and three times with DCM.

Cleavage of Fmoc-Protecting Group and Reaction with Nos-Cl (Resin 3). Resin 2 (1 g) was washed three times with DMF and treated with 50\% piperidine in DMF for 15 minutes. The resin was washed three times with DMF and five times with DCM and a solution of appropriate Nos- $\mathrm{Cl}$ (3 mmol) and lutidine (3.3 $\mathrm{mmol}, 382 \mu \mathrm{L}$ ) in $10 \mathrm{~mL} \mathrm{DCM}$ was added to the resin and resin slurry was shaken for 16 hours. The resin was washed three times with DCM.

\section{Fukuyama Modification of Mitsunobu N-Alkylation with 3,3-Diethoxypropan-1-ol/2,2-} Dimethoxyethan-1-ol (Resin 4 or 5). Resin 3 (0.5 g) in $20 \mathrm{~mL}$-plastic reaction vessel was washed three times with DCM and three times with anhydrous THF and a $0.1 \mathrm{M}$ solution of appropriate hydroxyaldehyde (1 mmol), $\mathrm{PPh}_{3}(1 \mathrm{mmol}, 0.29 \mathrm{~g})$, in $5 \mathrm{~mL}$ anhydrous THF was added to the reaction vessel. A $5 \mathrm{~mL}$-plastic reaction vessel was charged with $0.1 \mathrm{M}$ DIAD (1 mmol, $0.22 \mathrm{~mL}$ ) in $5 \mathrm{~mL}$ anhydrous THF. The latter syringe was connected to the plastic reaction vessel containing the resin $\mathbf{3}$. Connected syringes were left in a freezer for 30 minutes and the DIAD solution was drawn into the syringe with a resin. The resin slurry was shaken at rt for 16 hours. The resin was washed three times with anhydrous THF and three times with DCM. The reaction was repeated for quantitative alkylation except compounds $(\mathbf{S}, \mathbf{S}, \boldsymbol{R}, \boldsymbol{R})-\mathbf{6}$ (Entry 3, Table S1) and (R,R,S,S)-6 (Entry 7).

Cleavage of Protecting Groups, Cleavage from the Resin and Tandem Cyclization to Final Products (6, 12 - 19). For compounds 6, 12 - 18. Resin 4 (0.5 g) was treated with $5 \mathrm{~mL} 50 \%$ TFA in DCM at rt (for reaction time, see SI). TFA solution was collected, resin was washed three times with 50\% TFA in DCM 
and combined extracts were evaporated by a stream of nitrogen. For compounds 6 (Entry 2) and 19. Resin 4 and 5 (0.5 g) was treated with neat $\mathrm{HCOOH}$ at $50^{\circ} \mathrm{C}$ for 16 hours. The resin beads were filtered out and the $\mathrm{HCOOH}$ was evaporated by a stream of nitrogen.

\section{Isolation of Final Products $(6,12-19)$}

The acidic residues were dissolved in approximately $5 \mathrm{ml}$ acetonitrile (MeCN) and all products were purified by semi-preparative reverse phase HPLC by using mobile phase MeCN and 10 mM aqueous ammonium acetate.

\section{Analytical data}

(1S,3aS,6aR,10aR)-6-((4-nitrophenyl)sulfonyl)-11-oxododecahydro-5H-benzo[f]oxazolo[3,2a][1,5]diazocine-1-carboxamide<smiles>NC(=O)[C@@H]1CO[C@H]2CCN([S@](=O)c3ccc([N+](=O)[O-])cc3)[C@@H]3CCCC[C@H]3C(=O)N21</smiles>

\section{$(S, S, R, R)-6$ (Entry 1)}

Yield: $11.5 \mathrm{mg}(12 \%)$ of amorphous solid. ESI-MS m/z = 436, [M-NH $]^{+} .{ }^{1} \mathrm{H}$ NMR $\left(500 \mathrm{MHz}, \mathrm{DMSO}-d_{6}\right): \delta$ (ppm) 8.39 - 8.37 (m, 2 H), 8.07 - 8.06 (m, 2 H), 7.28 (br. s., 1 H), 6.88 (br. s., 1 H), 5.75 (dd, J = 10.9, 2.1 $\mathrm{Hz}, 1 \mathrm{H}), 4.04(\mathrm{dd}, J=9.4,7.1 \mathrm{~Hz}, 1 \mathrm{H}), 3.85(\mathrm{dd}, J=9.4,1.5 \mathrm{~Hz}, 1 \mathrm{H}), 3.73-3.70(\mathrm{~m}, 1 \mathrm{H}), 3.70$ - $3.64(\mathrm{~m}, 2$ H), 3.61 - $3.53(\mathrm{~m}, 1 \mathrm{H}), 2.68(\mathrm{td}, J=11.3,3.4 \mathrm{~Hz}, 1 \mathrm{H}), 1.98-1.91(\mathrm{~m}, 1 \mathrm{H}), 1.71$ - $1.63(\mathrm{~m}, 3 \mathrm{H}), 1.60$ $1.40(\mathrm{~m}, 4 \mathrm{H}), 1.34-1.23(\mathrm{~m}, 1 \mathrm{H}), 1.20-1.11(\mathrm{~m}, 1 \mathrm{H}) .{ }^{13} \mathrm{C}\left\{{ }^{1} \mathrm{H}\right\} \mathrm{NMR}\left(126 \mathrm{MHz}, \mathrm{DMSO}-d_{6}\right): \delta(\mathrm{ppm})$ 171.3, $169.3,149.6,146.1,128.5,124.5,88.1,68.3,60.2$, 57.9, 45.3, 38.7, 34.9, 29.2, 27.8, 24.4, 23.2. HRMS (HESI-Orbitrap): $m / z$ calcd for $\mathrm{C}_{19} \mathrm{H}_{25} \mathrm{~N}_{4} \mathrm{O}_{7} \mathrm{~S}[\mathrm{M}+\mathrm{H}]^{+} 453.1438$, found 453.1441 .

\section{$(S, S, R, R)-6$ (Entry 2)}


Yield: $3.3 \mathrm{mg}(10 \%)$ of amorphous solid. ESI-MS $m / z=436,\left[\mathrm{M}-\mathrm{NH}_{3}\right]^{+} .{ }^{1} \mathrm{H}$ NMR $\left(400 \mathrm{MHz}, \mathrm{DMSO}-d_{6}\right): \delta$ (ppm) 8.38 (dd, J = 8.7, 2.3 Hz, 2 H), 8.07 (dd, J = 8.7, 2.3 Hz, 2 H), 7.30 (br. s., 1 H), 6.90 (br. s, 1 H), 5.82 $5.68(\mathrm{~m}, 1 \mathrm{H}), 4.11$ - $3.97(\mathrm{~m}, 1 \mathrm{H}), 3.91$ - $3.79(\mathrm{~m}, 1 \mathrm{H}), 3.77$ - $3.51(\mathrm{~m}, 4 \mathrm{H}), 2.75$ - $2.61(\mathrm{~m}, 1 \mathrm{H}), 2.00$ $1.87(\mathrm{~m}, 1 \mathrm{H}), 1.73-1.37(\mathrm{~m}, 7 \mathrm{H}), 1.36-1.22(\mathrm{~m}, 1 \mathrm{H}), 1.21-1.07(\mathrm{~m}, 1 \mathrm{H}) .{ }^{13} \mathrm{C}\left\{{ }^{1} \mathrm{H}\right\} \mathrm{NMR}(101 \mathrm{MHz}$, DMSO- $d_{6}$ ): $\delta$ (ppm) 171.3, 169.3, 149.6, 146.1, 128.5, 124.5, 88.1, 68.3, 60.2, 57.9, 45.3, 38.7, 34.9, 29.2, 27.8, 24.4, 23.2. HRMS (HESI-Orbitrap): $m / z$ calcd for $\mathrm{C}_{19} \mathrm{H}_{25} \mathrm{~N}_{4} \mathrm{O}_{7} \mathrm{~S}[\mathrm{M}+\mathrm{H}]^{+} 453.1438$, found 453.1440 .

\section{$(S, S, R, R)-6$ (Entry 9)}

Yield: $4.6 \mathrm{mg}(8 \%)$ of amorphous solid. ESI-MS $m / z=436,\left[\mathrm{M}-\mathrm{NH}_{3}\right]^{+} .{ }^{1} \mathrm{H}$ NMR $\left(400 \mathrm{MHz}, \mathrm{DMSO}-d_{6}\right): \delta$ (ppm) 8.41 - 8.35 (m, 2 H), 8.10 - 8.04 (m, 2 H), 7.30 (br. s., 1 H), 6.91 (br. s., 1 H), 5.75 (dd, J = 10.9, 2.1 $\mathrm{Hz}, 1 \mathrm{H}), 4.04$ (dd, J = 9.4, $7.1 \mathrm{~Hz}, 1 \mathrm{H}$ ), 3.84 (dd, J = 9.4, $1.5 \mathrm{~Hz}, 1 \mathrm{H}), 3.74-3.49(\mathrm{~m}, 4 \mathrm{H}), 2.68$ (td, J = 3.4, $11.3 \mathrm{~Hz}, 1 \mathrm{H}), 2.02-1.88(\mathrm{~m}, 1 \mathrm{H}), 1.74-1.36(\mathrm{~m}, 7 \mathrm{H}), 1.35$ - $1.21(\mathrm{~m}, 1 \mathrm{H}), 1.21-1.08(\mathrm{~m}, 1 \mathrm{H})$.

\section{$(S, S, R, R)-6$ (Entry 3)}

Yield $13.4 \mathrm{mg}(24 \%)$ of amorphous solid. ESI-MS $m / z=436$, [M-NH $\left.]_{3}\right]^{+} .{ }^{1} \mathrm{H}$ NMR $\left(500 \mathrm{MHz}, \mathrm{DMSO}-d_{6}\right): \delta$ (ppm) 8.39 - 8.37 (m, 2 H), 8.07 - 8.06 (m, 2 H), 7.28 (br. s., 1 H), 6.88 (br. s., 1 H), 5.75 (dd, J = 11.0, 2.1 $\mathrm{Hz}, 1 \mathrm{H}), 4.04$ (dd, J = 9.4, $7.1 \mathrm{~Hz}, 1 \mathrm{H}), 3.85$ (dd, J = 9.4, $1.4 \mathrm{~Hz}, 1 \mathrm{H}), 3.74-3.70(\mathrm{~m}, 1 \mathrm{H}), 3.70$ - 3.63 (m, 2 H), 3.61 - $3.53(\mathrm{~m}, 1 \mathrm{H}), 2.68(\mathrm{td}, J=11.3,3.2 \mathrm{~Hz}, 1 \mathrm{H}), 2.00-1.89(\mathrm{~m}, 1 \mathrm{H}), 1.72-1.63(\mathrm{~m}, 3 \mathrm{H}), 1.60-$ $1.39(\mathrm{~m}, 4 \mathrm{H}), 1.34-1.23(\mathrm{~m}, 1 \mathrm{H}), 1.20-1.11(\mathrm{~m}, 1 \mathrm{H}) .{ }^{13} \mathrm{C}\left\{{ }^{1} \mathrm{H}\right\}$ NMR (126 MHz, DMSO-d 6 ): $\delta$ (ppm) 171.3, $169.3,149.6,146.1,128.5,124.6,88.1,68.4,60.2$, 58.0, 45.3, 38.7, 35.0, 29.2, 27.8, 24.4, 23.2. HRMS (HESI-Orbitrap): $m / z$ calcd for $\mathrm{C}_{19} \mathrm{H}_{25} \mathrm{~N}_{4} \mathrm{O}_{7} \mathrm{~S}[\mathrm{M}+\mathrm{H}]^{+} 453.1438$, found 453.1440 .

(1S,3aS,6aS,10aS)-6-((4-nitrophenyl)sulfonyl)-11-oxododecahydro-5H-benzo[f]oxazolo[3,2a][1,5]diazocine-1-carboxamide $(S, S, S, S)-6$

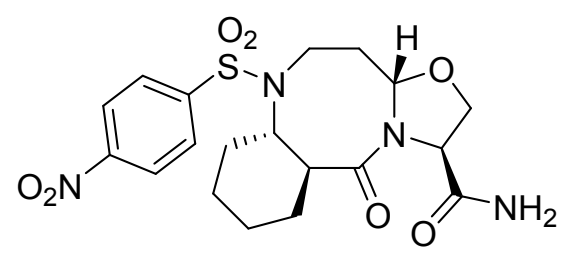

Yield $1.9 \mathrm{mg}(3 \%)$ of amorphous solid. ESI-MS $m / z=453,[\mathrm{M}+\mathrm{H}]^{+} .{ }^{1} \mathrm{H}$ NMR $\left(400 \mathrm{MHz}, \mathrm{DMSO}-d_{6}\right): \delta(\mathrm{ppm})$ 8.42 - 8.35 (m, 2 H), 8.19 - 8.12 (m, 2 H), 7.59 (br. s., 1 H), 6.54 (br. s., 1 H), 5.65 - 5.58 (m, 1 H), 4.58 (dd, 
$J=2.1,6.2 \mathrm{~Hz}, 1 \mathrm{H}), 4.22(\mathrm{dd}, J=2.1,8.0 \mathrm{~Hz}, 1 \mathrm{H}), 3.83(\mathrm{dd}, J=6.4,7.8 \mathrm{~Hz}, 1 \mathrm{H}), 3.73-3.60(\mathrm{~m}, 2 \mathrm{H}), 3.58$ - $3.46(\mathrm{~m}, 1 \mathrm{H}), 2.81$ - $2.70(\mathrm{~m}, 1 \mathrm{H}), 2.05$ - $1.92(\mathrm{~m}, 2 \mathrm{H}), 1.80$ - $1.46(\mathrm{~m}, 4 \mathrm{H}), 1.32$ - $1.05(\mathrm{~m}, 3 \mathrm{H}), 0.93$ (d, $J=10.1 \mathrm{~Hz}, 1 \mathrm{H}) .{ }^{13} \mathrm{C}\left\{{ }^{1} \mathrm{H}\right\}$ NMR (101 MHz, DMSO- $\left.d_{6}\right): \delta$ (ppm) 171.6, 171.3, 149.9, 145.5, 128.6, 124.8, 88.6, 67.0, 59.7, 59.3, 44.8, 40.2 (overlapped with DMSO- $d_{6}$ ), 37.9, 27.8, 27.7, 24.3, 23.2. HRMS (HESIOrbitrap): $m / z$ calcd for $\mathrm{C}_{19} \mathrm{H}_{25} \mathrm{~N}_{4} \mathrm{O}_{7} \mathrm{~S}[\mathrm{M}+\mathrm{H}]^{+} 453.1438$, found 453.1438 .

(1S,3aS,6aS,10aR)-6-((4-nitrophenyl)sulfonyl)-11-oxododecahydro-5H-benzo[f]oxazolo[3,2a][1,5]diazocine-1-carboxamide $(S, S, S, R)-6$

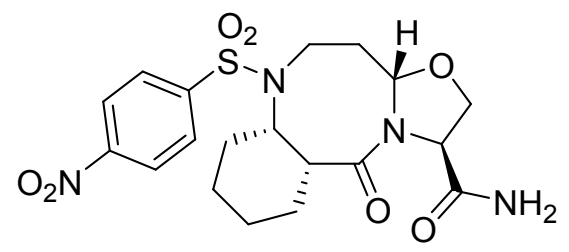

Yield $8.0 \mathrm{mg}(15 \%)$ of amorphous solid. ESI-MS $m / z=453,[\mathrm{M}+\mathrm{H}]^{+} .{ }^{1} \mathrm{H}$ NMR $\left(400 \mathrm{MHz}, \mathrm{DMSO}-d_{6}\right): \delta$ (ppm) $8.46-8.38$ (m, 2 H), $8.24-8.14$ (m, 2 H), 7.28 (br. s., 1 H), 6.93 (s, 1 H), 5.61 (dd, J = 10.1, 3.2 Hz, $1 \mathrm{H}), 4.31-4.23(\mathrm{~m}, 1 \mathrm{H}), 4.21-4.15(\mathrm{~m}, 1 \mathrm{H}), 3.90$ (dd, J = 9.6, 1.8, Hz, $2 \mathrm{H}), 3.51$ (dd, J = 15.6, $4.1 \mathrm{~Hz}, 2$ H), 3.00 (br. s., 1 H), 2.82 - 2.68 (m, 1 H), 2.16 - 2.00 (m, 2 H), 1.92 - 1.77 (m, 2 H), $1.67-1.57$ (m, 1 H), $1.56-1.43(\mathrm{~m}, 1 \mathrm{H}), 1.42-1.25(\mathrm{~m}, 3 \mathrm{H}) .{ }^{13} \mathrm{C}\left\{{ }^{1} \mathrm{H}\right\} \mathrm{NMR}\left(101 \mathrm{MHz}, \mathrm{DMSO}-d_{6}\right): \delta$ (ppm) 171.7, 169.1, 149.9, 145.2, 128.3, 124.9, 86.2, 68.2, 60.0, 58.1, 44.6, 40.1, 34.2, 29.7, 25.8, 25.7, 20.6. HRMS (ESI-TOF): $\mathrm{m} / \mathrm{z}$ calcd for $\mathrm{C}_{19} \mathrm{H}_{25} \mathrm{~N}_{4} \mathrm{O}_{7} \mathrm{~S}[\mathrm{M}+\mathrm{H}]^{+} 453.1444$, found 453.1438 .

(1R,3aR,6aS,10aS)-6-((4-nitrophenyl)sulfonyl)-11-oxododecahydro-5H-benzo[f]oxazolo[3,2a][1,5]diazocine-1-carboxamide<smiles></smiles> 


\section{$(R, R, S, S)-6$ (Entry 6)}

Yield $22.6 \mathrm{mg}$ (40\%) of amorphous solid. ESI-MS $m / z=436,\left[\mathrm{M}-\mathrm{NH}_{3}\right]^{+} .{ }^{1} \mathrm{H} \mathrm{NMR}\left(400 \mathrm{MHz}, \mathrm{DMSO}-d_{6}\right): \delta$ (ppm) 8.41 - 8.34 (m, 2 H), 8.10 - 8.03 (m, 2 H), 7.31 (br. s., 1 H), 6.91 (br. s., 1 H), 5.79 - 5.72 (m, 1 H), $4.08-4.00(m, 1 \mathrm{H}), 3.84(\mathrm{~d}, J=9.6 \mathrm{~Hz}, 1 \mathrm{H}), 3.74-3.52(\mathrm{~m}, 4 \mathrm{H}), 2.73-2.62(\mathrm{~m}, 1 \mathrm{H}), 2.02-1.88(\mathrm{~m}, 1 \mathrm{H})$, 1.74 - $1.36(\mathrm{~m}, 7 \mathrm{H}), 1.35$ - $1.22(\mathrm{~m}, 1 \mathrm{H}), 1.21$ - 1.07 (m, $1 \mathrm{H}) .{ }^{13} \mathrm{C}\left\{{ }^{1} \mathrm{H}\right\}$ NMR (101 MHz, DMSO-d $\left.)_{6}\right): \delta(p p m)$ 171.4 , 169.3, 149.7, 146.2, 128.6, 124.6, 88.1, 68.4, 60.2, 58.0, 45.4, 38.8, 35.0, 29.3, 27.8, 24.5, 23.3. HRMS (HESI-Orbitrap): $\mathrm{m} / z$ calcd for $\mathrm{C}_{19} \mathrm{H}_{25} \mathrm{~N}_{4} \mathrm{O}_{7} \mathrm{~S}[\mathrm{M}+\mathrm{H}]^{+} 453.1438$, found 453.1438 .

\section{$(R, R, S, S)-6$ (Entry 8)}

Yield $28.5 \mathrm{mg}$ (63\%) of amorphous solid. ESI-MS m/z = 436, [M-NH $]^{+} .{ }^{1} \mathrm{H}$ NMR $\left(400 \mathrm{MHz}, \mathrm{DMSO}-d_{6}\right): \delta$ (ppm) $8.41-8.35$ (m, 2 H), $8.10-8.03$ (m, 2 H), 7.31 (br. s., 1 H), 6.91 (br. s., 1 H), $5.79-5.72$ (m, 1 H), $4.08-4.00(\mathrm{~m}, 1 \mathrm{H}), 3.85(\mathrm{~d}, J=9.6 \mathrm{~Hz}, 1 \mathrm{H}), 3.75-3.51(\mathrm{~m}, 4 \mathrm{H}), 2.73-2.62(\mathrm{~m}, 1 \mathrm{H}), 2.02-1.89(\mathrm{~m}, 1 \mathrm{H})$, 1.75 - $1.37(\mathrm{~m}, 7 \mathrm{H}), 1.35$ - $1.22(\mathrm{~m}, 1 \mathrm{H}), 1.21$ - $1.08(\mathrm{~m}, 1 \mathrm{H}) .{ }^{13} \mathrm{C}\left\{{ }^{1} \mathrm{H}\right\}$ NMR (101 MHz, DMSO-d 6 ): $\delta(p p m)$ $171.4,169.3,149.7,146.2,128.6,124.6,88.1,68.4,60.2,58.0,45.4,38.8,35.0,29.3,27.9,24.5,23.3$. HRMS (HESI-Orbitrap): $m / z$ calcd for $\mathrm{C}_{19} \mathrm{H}_{25} \mathrm{~N}_{4} \mathrm{O}_{7} \mathrm{~S}[\mathrm{M}+\mathrm{H}]^{+} 453.1438$, found 453.1439 .

(1R,3aR,6aR,10aR)-6-((4-nitrophenyl)sulfonyl)-11-oxododecahydro-5H-benzo[f]oxazolo[3,2$a][1,5]$ diazocine-1-carboxamide $(R, R, R, R)-6$

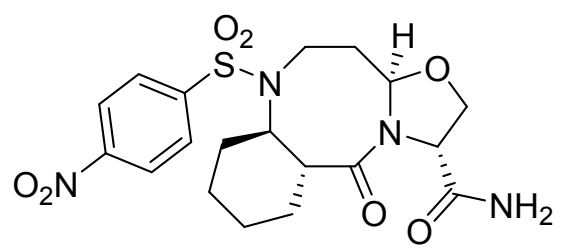

Yield $5.6 \mathrm{mg}(12 \%)$ of amorphous solid. ESI-MS $m / z=453,[\mathrm{M}+\mathrm{H}]^{+} .{ }^{1} \mathrm{H}$ NMR $\left(400 \mathrm{MHz}, \mathrm{DMSO}-d_{6}\right): \delta$ (ppm) 8.42 - 8.33 (m, 2 H), 8.18 - 8.13 (m, 2 H), 7.60 (br. s., 1 H), 6.54 (br. s., 1 H), 5.65 - 5.58 (m, 1 H), 4.61 - $4.53(\mathrm{~m}, 1 \mathrm{H}), 4.22$ (dd, J = 8.0, $2.1 \mathrm{~Hz}, 1 \mathrm{H}), 3.83$ (dd, J = 7.8, $6.9 \mathrm{~Hz}, 1 \mathrm{H}), 3.74-3.60(\mathrm{~m}, 2 \mathrm{H}), 3.52$ $(\mathrm{dd}, J=15.3,11.2 \mathrm{~Hz}, 1 \mathrm{H}), 2.81-2.70(\mathrm{~m}, 1 \mathrm{H}), 2.05-1.92(\mathrm{~m}, 1 \mathrm{H}), 1.82-1.47(\mathrm{~m}, 5 \mathrm{H}), 1.33-1.07(\mathrm{~m}, 3$ H), $0.92(\mathrm{~d}, J=9.2 \mathrm{~Hz}, 1 \mathrm{H}) .{ }^{13} \mathrm{C}\left\{{ }^{1} \mathrm{H}\right\} \mathrm{NMR}\left(101 \mathrm{MHz}\right.$, DMSO- $\left.d_{6}\right): \delta(\mathrm{ppm}) 171.6,171.3,149.9,145.5,128.6$, 124.8, 88.6, 67.0, 59.7, 59.3, 44.8, 37.9, 27.8, 27.7, 24.3, 23.2. HRMS (HESI-Orbitrap): $\mathrm{m} / \mathrm{z}$ calcd for $\mathrm{C}_{19} \mathrm{H}_{25} \mathrm{~N}_{4} \mathrm{O}_{7} \mathrm{~S}[\mathrm{M}+\mathrm{H}]^{+}$453.1438, found 453.1435. 
(1S,3aS,6aR,10aR)-N-(4-carbamoylbenzyl)-6-((4-nitrophenyl)sulfonyl)-11-oxododecahydro-5Hbenzo[f]oxazolo[3,2-a][1,5]diazocine-1-carboxamide $(S, S, R, R)-12$

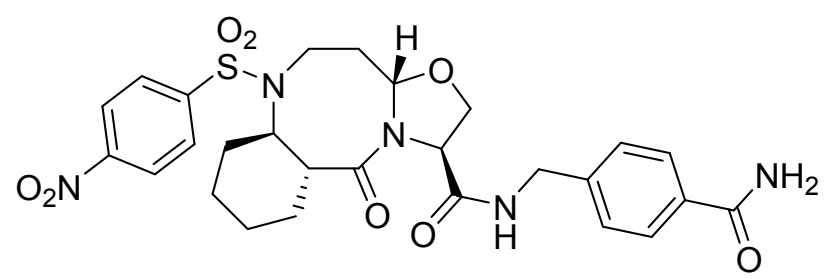

Yield $31.4 \mathrm{mg}(20 \%)$ of amorphous solid. ESI-MS $m / z=586,[\mathrm{M}+\mathrm{H}]^{+} .{ }^{1} \mathrm{H}$ NMR $\left(400 \mathrm{MHz}, \mathrm{DMSO}-d_{6}\right): \delta$ (ppm) 8.42 - 8.35 (m, 3 H), $8.11-8.07(\mathrm{~m}, 2 \mathrm{H}), 7.93(\mathrm{~s}, 1 \mathrm{H}), 7.80$ (d, J = 8.3 Hz, $2 \mathrm{H}), 7.31(\mathrm{~s}, 1 \mathrm{H}), 7.26$ (d, $J=8.2 \mathrm{~Hz}, 2 \mathrm{H}), 5.82(\mathrm{dd}, J=10.9,2.1 \mathrm{~Hz}, 1 \mathrm{H}), 4.37$ (dd, $J=16.1,6.4 \mathrm{~Hz}, 1 \mathrm{H}), 4.23(\mathrm{dd}, J=16.1,6.6 \mathrm{~Hz}, 1$ H), 4.12 (dd, J = 9.6, 7.1 Hz, 1 H), 3.89 (dd, J = 9.5, $1.6 \mathrm{~Hz}, 1 \mathrm{H}$ ), 3.82 (dd, J = 7.2, $1.6 \mathrm{~Hz}, 1 \mathrm{H}$ ), $3.76-3.57$ (m, 3 H), $2.70(\mathrm{td}, J=11.1,3.4 \mathrm{~Hz}, 1 \mathrm{H}), 2.05-1.94(\mathrm{~m}, 1 \mathrm{H}), 1.76-1.42(\mathrm{~m}, 7 \mathrm{H}), 1.37$ - $1.24(\mathrm{~m}, 1 \mathrm{H}), 1.19$ - 1.12 (m, $1 \mathrm{H}) .{ }^{13} \mathrm{C}\left\{{ }^{1} \mathrm{H}\right\}$ NMR (101 MHz, DMSO- $\left.d_{6}\right): \delta$ (ppm) 169.6, 169.5, 167.6, 149.6, 146.1, 142.7, 132.6, 128.5, 127.4, 126.4, 124.6, 88.2, 68.3, 60.2, 58.2, 45.4, 41.5, 38.5, 34.8, 29.3, 27.7, 24.5, 23.2. HRMS (HESI-Orbitrap): $m / z$ calcd for $\mathrm{C}_{27} \mathrm{H}_{32} \mathrm{~N}_{5} \mathrm{O}_{8} \mathrm{~S}[\mathrm{M}+\mathrm{H}]^{+} 586.1970$, found 586.1966.

(1S,3aS,6aR,10aR)-6-((2-nitro-4-(trifluoromethyl)phenyl)sulfonyl)-11-oxododecahydro-5Hbenzo[f]oxazolo[3,2-a][1,5]diazocine-1-carboxamide $(S, S, R, R)-13$<smiles>NC(=O)[C@@H]1CO[C@H]2CCN([O-])[C@H]3CCCC[C@H]3C(=O)N21</smiles>

Yield $3.1 \mathrm{mg}(4 \%)$ of amorphous solid. ESI-MS $m / z=504,\left[\mathrm{M}-\mathrm{NH}_{3}\right]^{+} .{ }^{1} \mathrm{H}$ NMR $\left(400 \mathrm{MHz}, \mathrm{DMSO}-\mathrm{d}_{6}\right): \delta$ (ppm) 8.60 (s, 1 H), 8.34 - 8.28 (m, 1 H), 8.21 (d, J = 8.7 Hz, 1 H), 7.35 (br. s., 1 H), 6.94 (br. s., 1 H), 5.82 (m, $1 \mathrm{H}), 4.22$ - $4.14(\mathrm{~m}, 1 \mathrm{H}), 4.07$ (d, J = 7.3 Hz, $1 \mathrm{H}), 3.91$ (d, J = 9.6 Hz, 1 H), 3.77 - $3.59(\mathrm{~m}, 3 \mathrm{H}), 2.80$ $2.69(\mathrm{~m}, 1 \mathrm{H}), 2.14-1.99(\mathrm{~m}, 1 \mathrm{H}), 1.79-1.38(\mathrm{~m}, 7 \mathrm{H}), 1.33-1.08(\mathrm{~m}, 2 \mathrm{H}) .{ }^{13} \mathrm{C}\left\{{ }^{1} \mathrm{H}\right\} \mathrm{NMR}(101 \mathrm{MHz}$, 
DMSO- $\left.d_{6}\right): \delta$ (ppm) 171.5, 169.0, 147.5, 135.5, 134.1 (q, $\left.J=34.5 \mathrm{~Hz}\right), 131.7,129.3(\mathrm{q}, J=3.8 \mathrm{~Hz}), 122.3$ ( $q, J=272.2 \mathrm{~Hz}$ ), $121.7(q, J=3.8 \mathrm{~Hz}$ ), 88.1, 68.5, 60.1, 57.9, 45.3, 40.2 (overlapped with DMSO-d ), 35.8 , 28.7, 27.8, 24.4, 23.2. HRMS (HESI-Orbitrap): $\mathrm{m} / \mathrm{z}$ calcd for $\mathrm{C}_{20} \mathrm{H}_{24} \mathrm{~N}_{4} \mathrm{O}_{7} \mathrm{~F}_{3} \mathrm{~S}[\mathrm{M}+\mathrm{H}]^{+} 521.1312$, found 521.1310 .

(1S,3aS,6aR,10aR)-6-((2,4-dinitrophenyl)sulfonyl)-11-oxododecahydro-5H-benzo[f]oxazolo[3,2-

$a][1,5]$ diazocine-1-carboxamide $(S, S, R, R)-14$

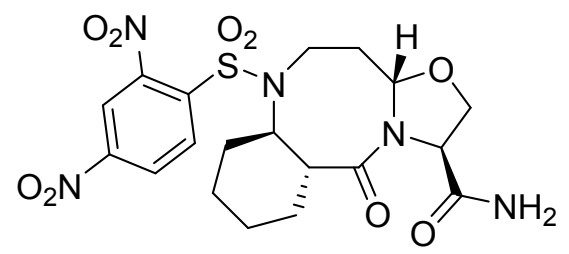

Yield $3.6 \mathrm{mg}(5 \%)$ of amorphous solid. ESI-MS $m / z=481,\left[\mathrm{M}-\mathrm{NH}_{3}\right]^{+} .{ }^{1} \mathrm{H}$ NMR $\left(400 \mathrm{MHz}, \mathrm{DMSO}-d_{6}\right): \delta$ (ppm) $8.96(\mathrm{~d}, J=2.3 \mathrm{~Hz}, 1 \mathrm{H}), 8.54(\mathrm{dd}, J=8.9,2.1 \mathrm{~Hz}, 1 \mathrm{H}), 8.35$ (d, J = 8.7 Hz, $1 \mathrm{H}$ ), 7.36 (br. s., $1 \mathrm{H})$, 6.94 (br. s., 1 H), $5.86-5.78(m, 1 \mathrm{H}), 4.23-4.16(\mathrm{~m}, 1 \mathrm{H}), 4.06(\mathrm{~d}, J=7.3 \mathrm{~Hz}, 1 \mathrm{H}), 3.90$ (d, J = 9.2 Hz, 1 H), 3.77 - $3.61(\mathrm{~m}, 3 \mathrm{H}), 2.75(\mathrm{td}, J=11.1,2.5 \mathrm{~Hz}, 1 \mathrm{H}), 2.14-2.01(\mathrm{~m}, 1 \mathrm{H}), 1.80$ - $1.68(\mathrm{~m}, 3 \mathrm{H}), 1.64$ $1.39(\mathrm{~m}, 4 \mathrm{H}), 1.31-1.26(\mathrm{~m}, 1 \mathrm{H}), 1.24-1.13(\mathrm{~m}, 1 \mathrm{H}) .{ }^{13} \mathrm{C}\left\{{ }^{1} \mathrm{H}\right\} \mathrm{NMR}\left(101 \mathrm{MHz}, \mathrm{DMSO}-d_{6}\right): \delta(p p m)$ 171.5, 167.0, 150.1, 147.3, 136.7, 132.0, 126.9, 119.8, 88.1, 68.5, 60.2, 57.9, 45.3, 38.7, 35.9, 28.7, 27.8, 24.4, 23.2. HRMS (HESI-Orbitrap): $m / z$ calcd for $\mathrm{C}_{19} \mathrm{H}_{24} \mathrm{~N}_{5} \mathrm{O}_{9} \mathrm{~S}[\mathrm{M}+\mathrm{H}]^{+} 498.1289$, found 498.1294.

(1S,3aS,6aR,10aR)-6-((2-nitrophenyl)sulfonyl)-11-oxododecahydro-5H-benzo[f]oxazolo[3,2$a][1,5]$ diazocine-1-carboxamide $(S, S, R, R)-15$

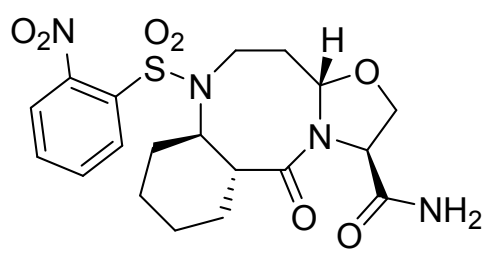


Yield $7.0 \mathrm{mg}(9 \%)$ of amorphous solid. ESI-MS $m / z=436,\left[\mathrm{M}-\mathrm{NH}_{3}\right]^{+} .{ }^{1} \mathrm{H}$ NMR $\left(400 \mathrm{MHz}, \mathrm{DMSO}-d_{6}\right): \delta$ (ppm) 8.06 - 8.00 (m, 1 H), 7.95 - 7.80 (m, 3 H), 7.34 (br. s., 1 H), 6.93 (br. s., 1 H), 5.80 (m, 1 H), 4.15 $4.04(\mathrm{~m}, 2 \mathrm{H}), 3.89(\mathrm{~d}, J=9.2 \mathrm{~Hz}, 1 \mathrm{H}), 3.77-3.54(\mathrm{~m}, 3 \mathrm{H}), 2.78-2.65(\mathrm{~m}, 1 \mathrm{H}), 2.06$ - $1.93(\mathrm{~m}, 1 \mathrm{H}), 1.78$ $1.35(\mathrm{~m}, 6 \mathrm{H}), 1.33-1.09(\mathrm{~m}, 3 \mathrm{H}) .{ }^{13} \mathrm{C}\left\{{ }^{1} \mathrm{H}\right\} \mathrm{NMR}\left(101 \mathrm{MHz}, \mathrm{DMSO}-d_{6}\right): \delta$ (ppm) 171.6, 169.1, 147.4, 134.8, 132.3, 131.9, 130.1, 123.8, 88.2, 68.4, 59.9, 58.0, 45.4, 40.2 (overlapped with DMSO- $d_{6}$ ), 35.8, 28.7, 28.0, 24.4, 23.2. HRMS (HESI-Orbitrap): $m / z$ calcd for $\mathrm{C}_{19} \mathrm{H}_{25} \mathrm{~N}_{4} \mathrm{O}_{7} \mathrm{~S}[\mathrm{M}+\mathrm{H}]^{+} 453.1438$, found 453.1435 .

(1S,3aS,6aR,10aR)-N-(4-carbamoylbenzyl)-6-((2-nitro-4-(trifluoromethyl)phenyl)sulfonyl)-11oxododecahydro-5H-benzo[f]oxazolo[3,2-a][1,5]diazocine-1-carboxamide $(S, S, R, R)$-16

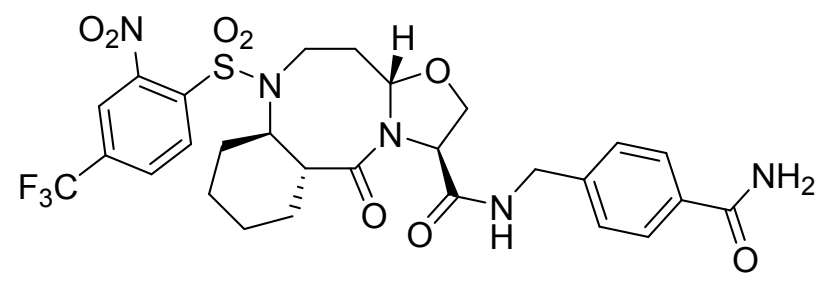

Yield $6.0 \mathrm{mg}$ (4 \%) of amorphous solid. ESI-MS m/z =654, $[\mathrm{M}+\mathrm{H}]^{+} .{ }^{1} \mathrm{H}$ NMR (400 MHz, DMSO- $\left.d_{6}\right): \delta(p p m)$ $8.62(\mathrm{~s}, 1 \mathrm{H}), 8.44(\mathrm{t}, J=6.0 \mathrm{~Hz}, 1 \mathrm{H}), 8.33(\mathrm{~d}, J=8.7 \mathrm{~Hz}, 1 \mathrm{H}), 8.23(\mathrm{~d}, J=8.2 \mathrm{~Hz}, 1 \mathrm{H}), 7.93$ (br. s., $1 \mathrm{H})$, $7.80(\mathrm{~d}, J=7.8 \mathrm{~Hz}, 2 \mathrm{H}), 7.36$ - $7.26(\mathrm{~m}, 3 \mathrm{H}), 5.93$ - $5.85(\mathrm{~m}, 1 \mathrm{H}), 4.42$ - $4.15(\mathrm{~m}, 4 \mathrm{H}), 3.99$ - $3.90(\mathrm{~m}, 1 \mathrm{H})$, 3.80 - $3.63(\mathrm{~m}, 3 \mathrm{H}), 2.81$ - $2.72(\mathrm{~m}, 1 \mathrm{H}), 2.17$ - $2.04(\mathrm{~m}, 1 \mathrm{H}), 1.82-1.41(\mathrm{~m}, 7 \mathrm{H}), 1.37$ - $1.09(\mathrm{~m}, 2 \mathrm{H})$. ${ }^{13} \mathrm{C}\left\{{ }^{1} \mathrm{H}\right\}$ NMR (101 MHz, DMSO- $\left.d_{6}\right): \delta$ (ppm) 169.7, 169.2, 167.7, 147.5, 142.8, 135.5, 134.1 (q, $J=34.5$ $\mathrm{Hz}), 132.6,131.7,129.3$ (q, $J=3.8 \mathrm{~Hz}), 127.4,126.5,122.5(\mathrm{q}, J=274.1 \mathrm{~Hz}), 121.7(\mathrm{q}, J=3.8 \mathrm{~Hz}), 88.3$, $68.4,60.1,58.2,45.4,41.6,40.2$ (overlapped with DMSO- $d_{6}$ ), 35.8, 28.7, 27.8, 24.4, 23.2. HRMS (HESIOrbitrap): $m / z$ calcd for $\mathrm{C}_{28} \mathrm{H}_{31} \mathrm{~N}_{5} \mathrm{O}_{8} \mathrm{~F}_{3} \mathrm{~S}[\mathrm{M}+\mathrm{H}]^{+} 654.1840$, found 654.1834 .

(1S,3aS,6aR,10aR)-N-(4-carbamoylbenzyl)-6-((2,4-dinitrophenyl)sulfonyl)-11-oxododecahydro-5Hbenzo[f]oxazolo[3,2-a][1,5]diazocine-1-carboxamide $(S, S, R, R)-17$<smiles>NC(=O)c1ccc(CNC(=O)[C@@H]2CO[C@H]3CCN([O-])[C@@H]4CCCC[C@H]4C(=O)N32)cc1</smiles> 
Yield $3.1 \mathrm{mg}(2 \%)$ of amorphous solid. ESI-MS m/z $=631,[\mathrm{M}+\mathrm{H}]^{+} .{ }^{1} \mathrm{H}$ NMR $\left(400 \mathrm{MHz}, \mathrm{DMSO}-d_{6}\right): \delta(\mathrm{ppm})$ $8.97(\mathrm{~d}, J=2.3 \mathrm{~Hz}, 1 \mathrm{H}), 8.55(\mathrm{dd}, J=8.7,2.3 \mathrm{~Hz}, 1 \mathrm{H}), 8.44(\mathrm{t}, J=6.0 \mathrm{~Hz}, 1 \mathrm{H}), 8.36(\mathrm{~d}, J=9.2 \mathrm{~Hz}, 1 \mathrm{H})$, 7.93 (br. s., 1 H), 7.80 (d, J = 8.2 Hz, 2 H), 7.29 (d, J = 8.2 Hz, 3 H), $5.94-5.79(m, 1$ H), 4.42 - 4.32 (m, 1 H), 4.31 - $4.22(\mathrm{~m}, 2 \mathrm{H}), 4.22$ - $4.16(\mathrm{~m}, 1 \mathrm{H}), 3.94(\mathrm{~d}, J=9.2 \mathrm{~Hz}, 1 \mathrm{H}), 3.78$ - $3.67(\mathrm{~m}, 3 \mathrm{H}), 2.82$ - $2.72(\mathrm{~m}, 1$ H), 2.18 - $2.04(\mathrm{~m}, 1 \mathrm{H}), 1.83$ - $1.71(\mathrm{~m}, 3 \mathrm{H}), 1.68$ - $1.56(\mathrm{~m}, 4 \mathrm{H}), 1.51$ - $1.40(\mathrm{~m}, 1 \mathrm{H}), 1.36$ - $1.10(\mathrm{~m}, 1 \mathrm{H})$. ${ }^{13} \mathrm{C}\left\{{ }^{1} \mathrm{H}\right\}$ NMR (101 MHz, DMSO- $\left.d_{6}\right): \delta$ (ppm) 169.7, 169.2, 167.6, 150.1, 147.3, 142.7, 136.7, 132.6, 132.0, $127.4,126.9,126.5,119.8,88.2,68.5,60.2,58.1,45.3,41.6,40.3,35.8,28.7,27.8,24.4$, 23.2. HRMS (HESI-Orbitrap): $m / z$ calcd for $\mathrm{C}_{27} \mathrm{H}_{31} \mathrm{~N}_{6} \mathrm{O}_{10} \mathrm{~S}[\mathrm{M}+\mathrm{H}]^{+}$631.1817, found 631.1814.

(1S,3aS,6aR,10aR)-N-(4-carbamoylbenzyl)-6-((2-nitrophenyl)sulfonyl)-11-oxododecahydro-5Hbenzo[f]oxazolo[3,2-a][1,5]diazocine-1-carboxamide $(S, S, R, R)-18$

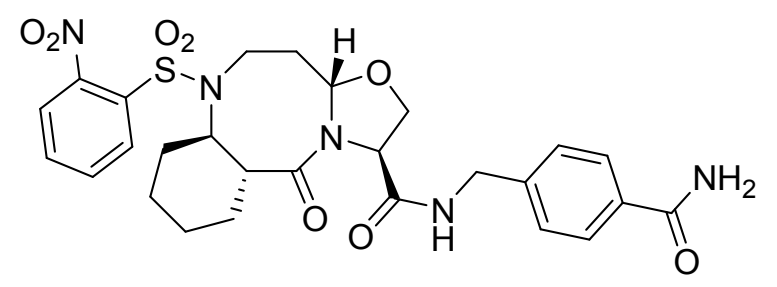

Yield $7.4 \mathrm{mg}(8 \%)$ of amorphous solid. ESI-MS $m / z=586,[\mathrm{M}+\mathrm{H}]]^{+} .{ }^{1} \mathrm{H}$ NMR $\left(400 \mathrm{MHz}, \mathrm{DMSO}-d_{6}\right): \delta(\mathrm{ppm})$ $8.42(\mathrm{t}, J=6.0 \mathrm{~Hz}, 1 \mathrm{H}), 8.05(\mathrm{~d}, J=7.8 \mathrm{~Hz}, 1 \mathrm{H}), 7.96-7.77(\mathrm{~m}, 6 \mathrm{H}), 7.30(\mathrm{~d}, J=8.2 \mathrm{~Hz}, 3 \mathrm{H}), 5.89-5.83$ $(\mathrm{m}, 1 \mathrm{H}), 4.43-4.15(\mathrm{~m}, 4 \mathrm{H}), 3.93(\mathrm{td}, J=7.6,5.4 \mathrm{~Hz}, 1 \mathrm{H}), 3.79-3.58(\mathrm{~m}, 3 \mathrm{H}), 2.78$ - $2.69(\mathrm{~m}, 1 \mathrm{H}), 2.11$ $1.98(\mathrm{~m}, 1 \mathrm{H}), 1.74(\mathrm{~d}, J=11.9 \mathrm{~Hz}, 2 \mathrm{H}), 1.66-1.53(\mathrm{~m}, 3 \mathrm{H}), 1.51-1.38(\mathrm{~m}, 1 \mathrm{H}), 1.33-1.09(\mathrm{~m}, 3 \mathrm{H})$. ${ }^{13} \mathrm{C}\left\{{ }^{1} \mathrm{H}\right\}$ NMR $\left(101 \mathrm{MHz}\right.$, DMSO- $\left.d_{6}\right): \delta$ (ppm) 169.8, 169.3, 167.7, 147.5, 142.7, 134.8, 132.6, 132.3, 131.9, $130.1,127.4,126.5,123.8,88.3,68.4,59.9,58.2$, 45.5, 41.6, 40.2 (overlapped with DMSO- $d_{6}$ ), 35.6, 28.7, 27.8, 24.4, 23.2. HRMS (HESI-Orbitrap): $m / z$ calcd for $\mathrm{C}_{27} \mathrm{H}_{32} \mathrm{~N}_{5} \mathrm{O}_{8} \mathrm{~S}[\mathrm{M}+\mathrm{H}]^{+} 586.1966$, found 586.1961.

(3S,5aR,9aR,11aS)-10-((4-nitrophenyl)sulfonyl)-5-oxododecahydrobenzo[e]oxazolo[3,2-

a][1,4]diazepine-3-carboxamide and (3S,5aS,9aS,11aR)-10-((4-nitrophenyl)sulfonyl)-5oxododecahydrobenzo[e]oxazolo[3,2- $a][1,4]$ diazepine-3-carboxamide $(S, R, R, S)-19$ and $(S, S, S, R)-19$ 

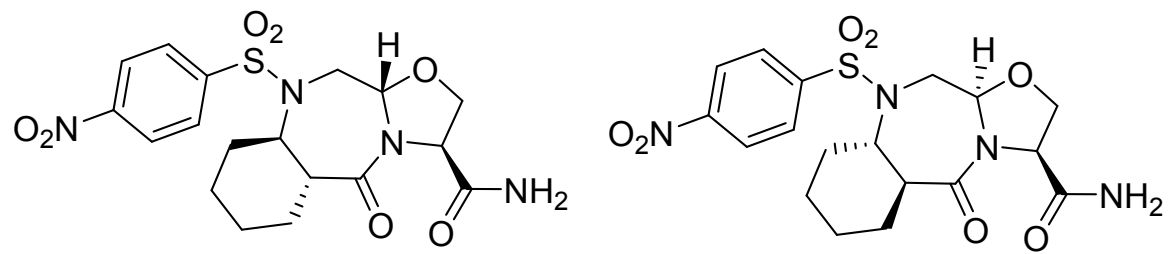

Isolated as a diastereomeric mixture; major diastereomer: Yield $2.4 \mathrm{mg}(7 \%)$ of amorphous solid. ESI-MS $m / z=439,[\mathrm{M}+\mathrm{H}]^{+} .{ }^{1} \mathrm{H}$ NMR $\left(500 \mathrm{MHz}, \mathrm{DMSO}-d_{6}\right): \delta(\mathrm{ppm}) 8.41-8.33(\mathrm{~m}, 2 \mathrm{H}), 8.00-7.96(\mathrm{~m}, 2 \mathrm{H}), 7.37$ (s, $1 \mathrm{H}), 6.96(\mathrm{~s}, 1 \mathrm{H}), 5.05-5.02(\mathrm{~m}, 1 \mathrm{H}), 4.21-4.16(\mathrm{~m}, 1 \mathrm{H}), 4.05-3.96(\mathrm{~m}, 3 \mathrm{H}), 3.91$ (app t, $1 \mathrm{H})$, $3.66(\mathrm{td}, J=11.5,3.8 \mathrm{~Hz}, 1 \mathrm{H}), 2.56-2.53(\mathrm{~m}, 1 \mathrm{H}), 1.85-1.10(\mathrm{~m}, 8 \mathrm{H}) .{ }^{13} \mathrm{C}\left\{{ }^{1} \mathrm{H}\right\} \mathrm{NMR}(126 \mathrm{MHz}$, DMSO$\left.d_{6}\right): \delta$ (ppm) 170.6, 167.9, 149.4, 146.3, 128.4, 124.2, 87.9, 69.7, 59.5, 57.6, 44.9, 43.1, 31.39, 26.7, 24.2, 23.4. HRMS (HESI-Orbitrap): $m / z$ calcd for $\mathrm{C}_{18} \mathrm{H}_{23} \mathrm{~N}_{4} \mathrm{O}_{7} \mathrm{~S}[\mathrm{M}+\mathrm{H}]^{+} 439.1282$, found 439.1279 .

\section{Acknowledgement}

This research was supported by the Department of Chemistry and Biochemistry, University of Notre Dame, by National Program of Sustainability (LO1304), and research grant 16-06446S from the Grant Agency of the Czech Republic (GACR). We would like to thank Dr. Sandra Benická for HRMS and SFC analyses.

\section{Supporting Information}

List of $[6+8+5]$ and $[6+7+5]$ fused heterocycles, SFC of Fmoc-trans-2-aminocyclohexane carboxylic acid, chemical shifts for model compounds $(S, S, R, R)-6,(S, S, R, R)-12,(S, R, R, S)-19$ and $(S, S, S, R)-19$, copies of ${ }^{1} H$ and ${ }^{13} \mathrm{C}\left\{{ }^{1} \mathrm{H}\right\}$ NMR spectra for all compounds

\section{References}

1. Wilk, W.; Zimmermann, T. J.; Kaiser, M.; Waldmann, H. Biol. Chem. Principles, implementation, and application of biology-oriented synthesis (BIOS). Biol. Chem. 2010, 391, 491-497.

2. Kaiser, M.; Wetzel, S.; Kumar, K.; Waldmann, H. Biology-inspired synthesis of compound libraries. Cell. Mol. Life Sci. 2008, 65, 1186-1201. 
3. Wetzel, S.; Klein, K.; Renner, S.; Rauh, D.; Oprea, T. I.; Mutzel, P.; Waldmann, H. Interactive exploration of chemical space with Scaffold Hunter. Nat. Chem. Biol. 2009, 5, 581-583.

4. Wetzel, S.; Bon, R. S.; Kumar, K.; Waldmann, H. Biology-Oriented Synthesis. Angew. Chem. Int. Ed. 2011, 50, 10800-10826.

5. van Hattum, H.; Waldmann, H. Biology-Oriented Synthesis: Harnessing the Power of Evolution. J. Am. Chem. Soc. 2014, 136, 11853-11859.

6. Lovering, F.; Bikker, J.; Humblet, C. Escape from Flatland: Increasing Saturation as an Approach to Improving Clinical Success. J. Med. Chem. 2009, 52, 6752-6756.

7. Lopez-Vallejo, F.; Giulianotti, M. A.; Houghten, R. A.; Medina-Franco, J. L. Expanding the medicinally relevant chemical space with compound libraries. Drug Discov. Today 2012, 17, 718-726.

8. Yazici, A.; Pyne, S. G. Intermolecular Addition Reactions of $N$-Acyliminium lons (Part 1). Synthesis 2009, 339-368.

9. Yazici, A.; Pyne, S. G. Intermolecular Addition Reactions of N-Acyliminium Ions (Part 2). Synthesis 2009, 513-541.

10. La-Venia, A.; Ventosa Andrés, P.; Krchňák, V. Peptidomimetics via Iminium Chemistry on Solid Phase: Single, Fused, and Bridged Heterocycles. Top. Heterocycl. Chem. 2015, 49, 105126.

11. Wu, P.; Nielsen, T. E. Scaffold Diversity from N-Acyliminium lons. Chem. Rev. 2017, 117, 78117856.

12. Diness, F.; Wang, Y.; Meldal, M. Intramolecular N-Acyliminium Cascade (INAIC) Reactions in Cyclization of Peptide-Like Molecules. In Solid-Phase Synthesis of Nitrogenous Heterocycles, Springer: Cham, 2017; pp 65-94.

13. Nielsen, T. E.; Meldal, M. Solid-phase synthesis of complex and pharmacologically interesting heterocycles. Curr. Opin. Drug Discovery Dev. 2009, 12, 798-810.

14. Ventosa-Andrés, P.; La-Venia, A.; Ripoll, C. A. B.; Hradilová, L.; Krchňák, V. Synthesis of NatureInspired Medium-Sized Fused Heterocycles from Amino Acids. Chem. - Eur. J. 2015, 21, 13112-13119.

15. La-Venia, A.; Dolenský, B.; Krchňák, V. Polymer-Supported Stereoselective Synthesis of Tetrahydro-2H-oxazolo[3,2-a]pyrazin-5(3H)-ones. ACS Comb. Sci. 2013, 15, 162-167.

16. Shiina, I. Total Synthesis of Natural 8- and 9-Membered Lactones: Recent Advancements in Medium-Sized Ring Formation. Chem. Rev. 2007, 107, 239-273.

17. Prunet, J. Progress in Metathesis Through Natural Product Synthesis. Eur. J. Org. Chem. 2011, 2011, 3634-3647. 
18. Schütznerová, E.; Oliver, A.; Slough, G. A.; Krchňák, V. Traceless Solid-Phase Synthesis of Fused Chiral Macrocycles via Conformational Constraint-Assisted Cyclic Iminium Formation. Chem. Eur. J. 2017, 21, 12876-12885.

19. Fukuyama, T.; Jow, C.-K.; Cheung, M. 2- and 4-Nitrobenzenesulfonamides: Exceptionally Versatile Means for Preparation of Secondary Amines and Protection of Amines. Tetrahedron Lett. 1995, 36, 6373-6374.

20. Mitsunobu, O. The Use of Diethyl Azodicarboxylate and Triphenylphosphine in Synthesis and Transformation of Natural Products. Synthesis 1981, 1-28.

21. Cankařová, N.; Krchňák, V. Polymer-Supported Stereoselective Synthesis of Benzimidazolinopiperazinones. J. Org. Chem. 2012, 77, 5687-5695.

22. Cankařová, N.; La Venia, A.; Krchňák, V. Polymer-Supported Stereoselective Synthesis of Tetrahydrobenzopyrazino-thiadiazinone Dioxides via $\mathrm{N}$-Sulfonyl Iminiums. ACS Comb. Sci. 2014, 16, 293-302.

23. La-Venia, A.; Ventosa Andrés, P.; Hradilová, L.; Krchňák, V. From Amino Acids to Nature-Inspired Molecular Scaffolds: Incorporation of Medium-Sized Bridged Heterocycles into a Peptide Backbone. J. Org. Chem. 2014, 79, 10378-10389.

24. Bui, C. T.; Rasoul, F. A.; Ercole, F.; Pham, Y.; Maeji, N. J. Efficiencies of reductive amination reactions on different solid supports. Tetrahedron Lett. 1998, 39, 9279-9282.

25. Krchňák, V.; Paděra, V. The Domino Blocks: A Simple Solution for Parallel Solid Phase Organic Synthesis. Bioorg. Med. Chem. Lett. 1998, 22, 3261-3264. 